\title{
The Role of White Matter Dysfunction and Leukoencephalopathy/Leukodystrophy Genes in the Aetiology of Frontotemporal Dementias: Implications for Novel Approaches to Therapeutics
}

\author{
Hiu Chuen Lok and John B. Kwok*
}

check for

updates

Citation: Lok, H.C.; Kwok, J.B. The Role of White Matter Dysfunction and Leukoencephalopathy/

Leukodystrophy Genes in the Aetiology of Frontotemporal Dementias: Implications for Novel Approaches to Therapeutics. Int. J. Mol. Sci. 2021, 22, 2541. https:// doi.org/10.3390/ijms22052541

Academic Editor: Antonio Pisani

Received: 3 February 2021

Accepted: 1 March 2021

Published: 3 March 2021

Publisher's Note: MDPI stays neutral with regard to jurisdictional claims in published maps and institutional affiliations.

Copyright: (c) 2021 by the authors. Licensee MDPI, Basel, Switzerland. This article is an open access article distributed under the terms and conditions of the Creative Commons Attribution (CC BY) license (https:/ / creativecommons.org/licenses/by/ $4.0 /)$.
School of Medical Sciences, Faculty of Medicine and Health Sciences, University of Sydney,

Camperdown, NSW 2006, Australia; hiu.lok@sydney.edu.au

* Correspondence: john.kwok@sydney.edu.au

\begin{abstract}
Frontotemporal dementia (FTD) is a common cause of presenile dementia and is characterized by behavioural and/or language changes and progressive cognitive deficits. Genetics is an important component in the aetiology of FTD, with positive family history of dementia reported for $40 \%$ of cases. This review synthesizes current knowledge of the known major FTD genes, including C9orf72 (chromosome 9 open reading frame 72), MAPT (microtubule-associated protein tau) and GRN (granulin), and their impact on neuronal and glial pathology. Further, evidence for white matter dysfunction in the aetiology of FTD and the clinical, neuroimaging and genetic overlap between FTD and leukodystrophy/leukoencephalopathy are discussed. The review highlights the role of common variants and mutations in genes such as CSF1R (colony-stimulating factor 1 receptor), CYP27A1 (cytochrome P450 family 27 subfamily A member 1), TREM2 (triggering receptor expressed on myeloid cells 2) and TMEM106B (transmembrane protein 106B) that play an integral role in microglia and oligodendrocyte function. Finally, pharmacological and non-pharmacological approaches for enhancing remyelination are discussed in terms of future treatments of FTD.
\end{abstract}

Keywords: frontotemporal dementia; leukodystrophy; leukoencephalopathy; white matter; genetics; therapeutics

\section{Introduction}

Frontotemporal dementia (FTD) syndromes are a heterogeneous group of proteinopathies, characterized by progressive degeneration of the frontal and/or temporal lobes. Clinically, they are divided into three subtypes. The behavioural variant FTD (bvFTD) is characterized by progressive deterioration of personality, social comportment and cognition [1], while the language variant progressive non-fluent aphasia (PNFA) is characterized by preserved comprehension but with poor expression of language. Semantic dementia (SD) is another language variant, with relatively preserved episodic memory and speech fluency, but lacking in content and with impaired comprehension of words [2]. Due to the heterogeneity of clinical presentations and underlying neuropathology, diagnosis and treatment of FTD has been challenging. Recently, our understanding of FTD has been greatly improved by the identification of causal genes that initiate and drive the neurodegenerative process. Previously, investigations of the pathogenic mechanisms of established causal FTD genes have focused on their impact on neuronal function. We now recognize that certain genes, such as granulin (GRN), have a significant impact on glia function, and mutation carriers show a specific pattern of white matter abnormalities. Further, genome-wide association studies (GWAS) and next-generation sequencing (NGS) of clinical and neuropathological FTD cohorts have identified a number of novel FTD genes associated with myelin or white matter abnormalities. In this review, we will synthesize current knowledge of the known FTD genes in terms of their impact on neuronal and glia neuropathology 
and function. We will examine the role of white matter in the aetiology of FTD and the clinical, neuroimaging and genetic overlap between FTD and conditions with white matter dysfunction (leukodystrophy and leukoencephalopathy). These insights could lead to a better understanding of pathogenic mechanisms and identify potential therapeutics for this complex disease.

\section{The Genetics of Frontotemporal Dementia and Relation to Neuropathological Subtypes}

Genetics is an important component in the aetiology of FTD, with approximately $10 \%$ of cases being autosomal dominant and $40 \%$ of patients having a family history of dementia [3]. BvFTD is highly heritable, with $37 \%$ of cases having strong family history of dementia (Goldman scores of $\leq 2$ ), while the language variants PNFA and SD have lower incidence of positive family history $(12.5 \%$ and $5.6 \%$, respectively) [3]. Microtubuleassociated protein tau (MAPT) [4], granulin $(G R N)$ [5,6] and chromosome 9 open reading frame $72(C 9 o r f 72)[7,8]$ are the three most common genes causal of FTD and together account for $30-50 \%$ of familial FTD [9,10]. In addition, tank-binding kinase 1 (TBK1) is found in 1-2\% of total FTD cases [11,12]. Less common causal genes such as those for valosin-containing protein $(V C P)$, chromatin-modifying protein $2 \mathrm{~B}(C H M P 2 B)$, TAR-DNAbinding protein 43 (TARDBP), fused in sarcoma (FUS), coiled-coil-helix-coiled-coil-helix domain-containing 10 (CHCHD10) and triggering receptor expressed on myeloid cells 2 (TREM2) are known to contribute to $<5 \%$ of all FTD cases $[10,13,14]$. Our group has recently identified CYLD as a causal gene for FTD and amyotrophic lateral sclerosis (ALS), but it appears to be a relatively rare cause of the disease $[15,16]$.

The three FTD clinical sub-types display significant regional difference in grey matter structural atrophy and their connecting white matter tracts, with bvFTD showing specific prefrontal cortex and striatum grey matter atrophy and greater cerebellar white matter loss compared to other FTD subtypes [17]. Correspondingly, each causal gene is also associated with particular sub-types of FTD in terms of neuronal and glial pathology. The most common genetic causes of FTD will be discussed briefly in regard to their impact on neuropathology and their associated clinical and neuroimaging phenotypes.

\subsection{Frontotemporal Lobar Degeneration-Tau (FTLD-Tau) $M A P T$}

MAPT variants account for $20 \%$ of heritable FTD cases and are responsible for most familial cases with FTLD-Tau pathology [4], which is characterized by the presence of hyperphosphorylated tau inclusions, resulting from the disruption of tau binding to tubulin due to MAPT mutations $[18,19]$. Based on the biochemical composition and morphology of the inclusions, FTLD-Tau is further subtyped into Pick's disease, corticobasal syndrome (CBS) and progressive supranuclear palsy (PSP), in which either three-repeat or four-repeat tau is primarily deposited in neurons [20]. Our group recently confirmed that in globular glial tauopathy (GGT), four-repeat tau is primarily deposited in oligodendrocytes and astrocytes [21].

The main clinical subtype for MAPT mutation carriers is the behavioral variant (bvFTD), which can be concomitant with a dominant Parkinsonism phenotype such as CBS or PSP [22-24]. Neuroimaging studies in these patients have shown relatively symmetrical anteromedial temporal lobe and orbito-frontal grey matter atrophy $[25,26]$ that is responsible for the behavioral and semantic deficits in these patients.

\subsection{Frontotemporal Lobar Degeneration-TDP (FTLD-TDP)}

Approximately 50\% of all FTLD cases are FTLD-TDP [27]. FTLD-TDP is characterized by the accumulation of tau-negative, ubiquitin-positive inclusions that are formed from ubiquitinated and hyperphosphorylated abnormal C-terminus fragments of TAR DNAbinding protein 43 (TDP-43) [28]. Based on the cortical distribution, intracellular location and morphology of these inclusions, FTLD-TDP neuropathology is further classified into 
types A to D [29,30]. To date, FTD genes associated with this form of FTD neuropathology include GRN, C9orf72 and TBK1, whose features will be discussed below.

\subsubsection{C9orf72}

As much as $85 \%$ of FTD cases caused by C9orf 72 expansions are associated with the bvFTD subtype [31], while $22.31 \%$ of C9orf72 expansion carriers display additional degeneration of motor neurons or FTLD with amyotrophic lateral sclerosis (FTLD-ALS) [31,32]. The diffuse, widespread patterns of atrophy predominantly at the frontal and anterior temporal lobes, parietal lobes and the cerebellum lead to a broad range of clinical, cognitive and psychiatric symptoms [26,33]. Although the repeat expansion in C9orf72 is the most common cause of FTD and ALS in Europe and North America [34], it is extremely rare in Asian and the Middle Eastern cohorts [34-37]. Our group has confirmed the relatively high prevalence of the C9orf72 expansion in Australian and Spanish populations [38,39].

The neuropathology associated with C9orf72 expansion is a combination of typical ALS and Type B or pure Type A [32,40-42] TDP neuropathology. C9orf72 expansion was shown to impair the ability to degrade TDP-43, leading to TDP-43 accumulation in neurons and, occasionally, oligodendrocytes [43]. In addition, the glycine-arginine repeat protein [poly(GR)] translated from the expanded G4C2 repeats was shown to sequester full-length TDP-43, potentially resulting in the formation of TDP-43 inclusions [44]. Both RNA foci and dipeptide repeats predominantly impact on neuronal cell types [7].

\subsubsection{TBK1}

Loss-of-function mutations in TBK1 are found in ALS, FTD and ALS-FTD cases [12], with bvFTD being the most common observed clinical phenotype [12,32,45]. However, TBK1 variants are also associated with PNFA [45] and CBS [46]. Phenotypic heterogeneity is also observed for this gene, with multiple clinical phenotypes being observed within the same family $[32,46]$. TBK1 mutations are known to give rise to both FTLD-TDP subtype A [47] and B [12,32,45,48] neuropathology, with reports of severe neuronal loss [12,45,46], neuronal cytoplasmic inclusion $[12,47]$ and gliosis $[45,46]$.

\subsubsection{GRN}

The majority of GRN mutations are loss-of-function [24] and account for 5-20\% of familial FTD cases and 1-5\% of apparently sporadic FTD [6], giving rise to Type A FTLDTDP neuropathology [49]. This FTLD-TDP subtype, is primarily characterized by neuronal nuclear and/or cytoplasmic inclusions and dystrophic neurites [50], as well as oligodendrocyte inclusions [51]. To date, several mechanisms which link GRN mutations to FTLD-TDP pathology have been proposed: progranulin-mediated caspase 3-dependent cleavage of TDP-43 [52], sortilin-mediated progranulin endocytosis [53] and impaired autophagy [54] in the neurons. Of note, GRN is a growth factor and modulator of microglia, and mutation carriers have enhanced microglia activation [50] and gliosis [55,56] upon neuropathological examination.

FTD associated with $G R N$ is highly heterogeneous in age of onset and clinical presentations, even for the same variant [57]. GRN variants have been associated with parkinsonism, CBS and Alzheimer's disease (AD) [58,59]. Over $50 \%$ of GRN variant carriers present bvFTD followed by PNFA, and less than $10 \%$ are affected by CBS, AD and schizophrenia $[24,60]$. Indeed, multiple studies have shown that PNFA is more common in GRN variant carriers than in carriers of other mutations [24,31,32], consistent with the FTLDTDP subtype A, which is usually associated with bvFTD and PNFA [61]. Neuroimaging of mutation carriers revealed asymmetrical atrophy in the frontal, temporal and interior parietal lobe $[25,26,58]$. Of interest, white matter hyperintensities and white matter lesions are often seen on MRI brain scans of GRN-associated FTD [62-66], and this aspect will be further discussed in later sections. 


\section{White Matter Changes in FTD}

White matter involvement in FTD has been widely reported [26,66-77], suggesting a role for glial cells in the aetiology of the disease. White matter comprises the axons and their myelin sheath as well as the glia (oligodendrocytes, astrocytes and microglia) [78] and is crucial for cognitive and electrophysiological functions by coordinating rapid communication between different regions of the brain [79]. The myelin sheath is produced by oligodendrocytes wrapped around axons [80] (Figure 1), and disruption of this process leads to the absence of myelin production or its degeneration [79].

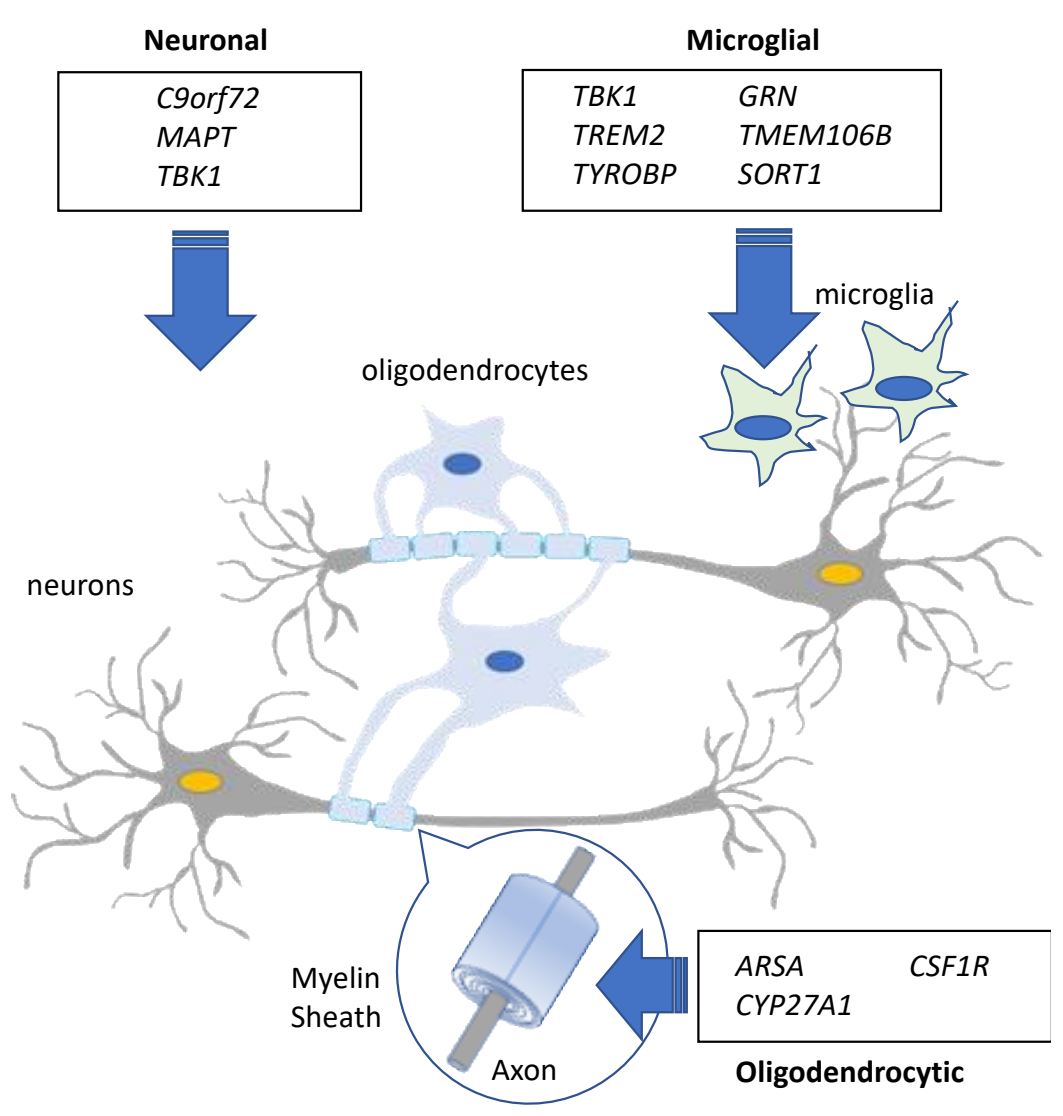

Figure 1. Schematic diagram of the relationship between neurons, oligodendrocytes and microglia. White matter comprises the myelin sheath covering the axons of neurons and is secreted by mature oligodendrocytes, as well as other glial cells such as microglia. Mutations and rare variants in established and candidate causal FTD genes can impact both neuronal and glial cells.

White matter alteration is prevalent in early symptomatic phase [74,75,81] and familial pre-symptomatic FTD [82-85]. White matter atrophy has also been reported in neuropathologically confirmed cases [86,87]. Diffusion tensor imaging has demonstrated selective reduction in white matter in the superior longitudinal fasciculus that interconnects the frontal and occipital and the temporal and parietal regions [74], which was found to correlate with behavior deficits in patient cohorts [74]. Similarly, Agosta et al. identified distinct structural network changes in white matter associated with specific neurobehavioral components, e.g., white matter changes in the frontotemporal regions are linked to apathy and impulsivity in bvFTD [88].

Consistent and widespread white matter tract pathology has been reported in bvFTD patients, compared to clinically normal subjects and those with $\mathrm{AD}$ and other forms of dementia [81,89]. A subgroup of the cohort carrying MAPT and C9orf72 mutations exhibited a relatively discrete and distinctive white matter profile that showed alterations in white matter within the left anterior temporal pole when compared to control and Alzheimer's disease subjects [81]. Further longitudinal studies of pre-symptomatic and 
symptomatic carriers of C9orf72, MAPT and GRN mutations have revealed early and widespread loss of white matter integrity in pre-symptomatic FTD, and there were clear genotypic "fingerprints" of white matter loss associated with each disease gene [82-85]. Since white matter is primarily composed of lipids, the imaging abnormalities observed in FTD brains could reflect the consequences of lipid metabolism dysregulation.

\section{Lipid Metabolism in White Matter and Relevance to FTD}

The human myelin lipidome consists of 700 different lipid moieties, $60 \%$ of which are species that are classified as phosphatidylcholines, phosphatidylethanolamines, sphingomyelins, cerebrosides and sulfatides [90]. The molar ratio of the major lipid components of myelin is kept constant, with cholesterol, glycerophospholipids and glycosphingolipids (in particular, galactocerebrosides) present at a ratio of around 4:4:2 [91], whose disruptions have frequently been associated with myelin dysfunction.

Lipid molecules in the brain are involved in energy storage, maintaining the structural integrity of the nervous system, signal transduction, modulation of membrane fluidity, trafficking of membrane proteins/receptors, cytoskeletal organization and neurotransmission $[92,93]$. The majority of brain cholesterol $(\sim 70 \%)$ is found in the myelin sheath; cholesterol is also an essential component of synapses and dendrites. Unsurprisingly, changes in brain lipid metabolism have been linked to AD [94-97], Parkinson's disease (PD) [98,99], Huntington's disease [100-103], ALS [104,105] and multiple sclerosis [106].

Changes in brain lipid metabolism are also evident in FTD. Lipidomic analysis performed on the plasma of bvFTD and AD patients has revealed a significant increase in triglycerides and decreases in phosphatidylserine and phosphatidylglycerol in bvFTD patients compared to AD patients $[107,108]$. Further, there were strong correlations between changes in certain lipids associated with mitochondrial energy production, proinflammatory pathways or oxidative damages and the pathophysiological changes associated with FTD, which can potentially be used as FTD biomarkers [109].

\section{Granulin Mutations: A Model for Understanding the Role of Lipid Dysregulation and White Matter Changes in FTD}

$G R N$ variants frequently lead to extensive gliosis and loss of myelin in the underlying white matter $[55,56,110,111]$. White matter hyperintensities and white matter lesions are often seen on MRI scans of the brains of patients carrying GRN mutations [62-66]. Lipidomic analysis has shown dosage-dependent differences in brain lipids from humans and transgenic mice with progranulin deficiency [112]. These observations point to alterations in brain lipid metabolism as a result of GRN mutation. Indeed, homozygous carriers of GRN mutations develop young adult-onset neuronal ceroid lipofuscinosis (NCL), a lysosomal storage disease characterized by lipofuscin deposition [113,114].

While the exact mechanism that links GRN mutations to dysregulation of lipid metabolism remains to be elucidated, the presence of the lipofuscinosis phenotype in GRN mutation carriers implicates lysosome regulation [115,116]. Indeed, sortilin, the endocytotic receptor responsible for lysosomal progranulin trafficking [53], has been shown to be a regulator of lipoprotein metabolism [117]. In addition, the loss of granulin has been shown to impact lipid metabolism by altering saposins, cofactors for lysosomal lipid hydrolases, in the brain tissue of GRN mutation carriers and $\mathrm{Grn}^{-/-}$mice [112]. It was also reported that progranulin facilitates the lysosomal trafficking of prosaposin, the precursor of saposin which is essential for the lysosomal degradation of glycosphingolipids [118]. Of interest, the activity of beta-glucocerebrosidase, a sphingolipid-metabolizing enzyme, was impaired in FTD phenotypic $\mathrm{Grn}^{-/-}$mice and FTD patients carrying GRN mutations [119].

\section{Leukoencephalopathies/Leukodystrophies as Part of the FTD Spectrum}

Leukoencephalopathy is a collective term for a group of heterogeneous primary white matter disorders that can be either acquired or hereditary. Leukodystrophies-a term that derives from "leuko" = white, "dys" = lack of and "trophy" = growth-are heritable leukoencephalopathies. Leukodystrophy is defined as "heritable disorders affecting the 
white matter of the central nervous system, sharing glial cell or myelin sheath abnormalities, the neuropathology of which is primarily characterized by the involvement of oligodendrocytes, astrocytes and other non-neuronal cell types, although in many disorders the mechanism of disease remains unknown, and in other cases is suspected to include significant axonal pathology" [120].

Leukodystrophies are highly variable in age of onset and clinical manifestations [120,121], which include dementia, movement disorders, ataxia and upper motor neuron signs concomitant with hyperintense signal abnormalities in the brain/spinal cord on T2-weighted MRI [122]. Leukodystrophies can be broadly divided into hypomyelinating leukodystrophies (HLD) and demyelinating leukodystrophies, referring to defects in myelin developments and progressive deterioration of normally developed myelin, respectively [123].

The diagnosis of leukodystrophies is slow and challenging, and the prognosis of patients is poor as a result of very limited therapies, which are only beneficial in the early onset of the diseases [121]. Recent advances in sequencing technology have led to the rapid identification of the underlying gene defect and a more accurate diagnosis of leukodystrophies. Indeed, as a result of the emergence of whole-exome sequencing, the percentage of leukodystrophy cases without specific diagnosis dropped from about $50 \%$ in 2010 to $20-30 \%$ in 2016 [124,125]. The genetic diagnosis can be highly beneficial in terms of identifying therapeutic targets, thus allowing, for example, the administration of the relevant recombinant enzyme (enzyme replacement therapy), as done for the treatment of metachromatic leukodystrophy due to Arylsulfatase A (ARSA) mutations [126].

It is of interest to note that while the major FTD causal genes such as MAPT [4], GRN $[5,6]$ and C9orf $72[7,8]$ were identified using genetic linkage studies of large pedigrees, these approaches have limited capacity for the identification of variants with modest effect sizes [127]. These limitations have been bridged by the emergence of GWAS and NGS for the identification of novel disease genes and pathways associated with FTD. Indeed, GWAS and NGS performed on FTD patients have identified a significant portion of FTD risk genes involved in lipid metabolism and leukodystrophy/leukoencephalopathies, thus confirming a link between dysregulation in lipid metabolism, white matter dysfunction and FTD.

\section{GWAS and Susceptibility Loci for FTD}

GWAS is based on the rationale of the "common disease, common variant" hypothesis that attributes common diseases to allelic variants that are present in more than $1-5 \%$ of the population [127]. The association between multiple allele or genotype frequencies within the whole genome and pathological traits is rapidly determined using specific genotyping arrays [128]. To date, multiple GWAS performed on FTD cohorts [129-142] have identified genes with diverse biological functions associated with disease, as well as shared pathways with other neurodegenerative diseases such as AD and PD [136] (Table 1). A notable portion of these genes have links to lipid metabolism or glial function: mutation of TMEM106B causes childhood-onset leukodystrophy, a hereditary white matter disease [143], and APOE, TOMM40 and LRRK2 are involved in lipid metabolism [144-147].

Table 1. Genes identified by genome-wide association studies (GWAS) that show association with FTD and impact on white matter.

\begin{tabular}{cccc}
\hline Genes & Protein & Function(s) & White Matter Pathology/Disease \\
\hline TMEM106B [129,131] & Transmembrane protein 106B & Unknown & Hypomyelinating leukodystrophy \\
\hline APOE $[136,141]$ & Apolipoprotein E & Lipid Metabolism & White matter hyperintensities upon \\
MRI [148]
\end{tabular}


Table 1. Cont.

\begin{tabular}{cccc}
\hline Genes & Protein & Function(s) & White Matter Pathology/Disease \\
\hline CTSC [135] & Cathespin C & $\begin{array}{c}\text { Activation of serine proteases } \\
\text { in immune/inflammation }\end{array}$ & Not described \\
TOMM40 [141] & $\begin{array}{c}\text { Translocase of the outer } \\
\text { mitochondrial } \\
\text { membrane complex }\end{array}$ & $\begin{array}{c}\text { Mitochondrial protein } \\
\text { transport }\end{array}$ & $\begin{array}{c}\text { Lower white matter integrity upon } \\
\text { MRI [150] }\end{array}$ \\
\hline GFRA2 [132] & GDNF Family Receptor Alpha 2 & $\begin{array}{c}\text { Cell surface receptor for glial } \\
\text { cell line-derived neurotrophic } \\
\text { factor and neurturin }\end{array}$ & Not described \\
\hline
\end{tabular}

\section{NGS and Rare Variants in FTD}

The "rare variants" hypothesis postulates that rare variants, primarily defined as having allele frequency $<0.001$ in the general population, could provide an explanation for a portion of missing heritability observed in twin studies [151] and impact on clinical phenotypes such as severity and age of onset [152]. NGS can rapidly screen the whole genome (whole-genome sequencing, WGS), specific loci or selected candidate genes (targeted sequencing), or exons of all coding genes (whole-exome sequencing, WES), thus enabling the parallel analysis of groups of interacting genes that contribute to the aetiology of a disease [151,153]. This approach has identified rare variants in known FTD genes as well as a number of rare variants in hitherto unsuspected genes with a role in lipid/white matter metabolism $[37,45,151,152,154-164]$ (Table 2). For example, SNCA has been implicated as a lipid-binding protein [165-167], SORT1 is a known regulator of lipoprotein metabolism [117], ABCA7 is a lipid transporter [168], and the multi-faceted LRRK2 has roles in lipid storage and ceramide metabolism in the brain [144,145].

To date, there are over 60 genes with diverse biological functions that have been associated with leukodystrophy/genetic leukoencephalopathies $[169,170]$, and there is growing evidence for a substantial overlap of leukodystrophy/leukoencephalopathy genes and FTD genes. Indeed, rare variants of ARSA [171,172], CSF1R [37,173,174], TREM2 [156,163,175-177], TYROBP [178], NOTCH3 [179] and CYP27A1 [180] have been identified as potential genetic causes of patients with clinical features of FTD. A study by Sirkis et al. [181] showed that most genes implicated in both leukodystrophy and FTD risk are differentially expressed in FTLD postmortem brain and that leukodystrophy/FTDassociated genes are interconnected with genes regulating immunological function and lysosomal homeostasis [181]. Respectively, these findings highlight the involvement of white matter and the dysregulation of lipid metabolism in the pathogenesis of FTD. The most commonly reported leukodystrophy genes in FTD cases will be discussed in greater detail.

\subsection{TMEM106B}

TMEM106B belongs to the TMEM106 family of Type II transmembrane proteins, mainly localized in lysosomes [182-184]. TMEM106B variants are known risk modifiers for FTD $[129,130,185,186]$, while a single TMEM106B mutation is responsible for five unrelated cases of hypomyelinating leukodystrophy $[143,187]$. To date, the exact mechanism through which TMEM106B variants are linked to hypomyelinating leukodystrophy and FTD risks remains to be fully elucidated, although studies have suggested that it involves TMEM106Bmediated lysosomal regulation/transport [188]. Of interest, TMEM106B-deficient mice showed impaired axonal lysosome transport and axonal autophagy [189] and myelin deficits [190], which suggest a role of TMEM106B in myelination. 
Table 2. FTD genes with rare variants identified by next-generation sequencing (NGS) and their role in white matter dysfunction.

\begin{tabular}{|c|c|c|c|}
\hline Genes & Protein & Function & White Matter Pathology/Disease \\
\hline AARS2 [37] & Alanyl-tRNA synthetase 2 & Translation & Leukodystrophy [191] \\
\hline$A B C A 7[156]$ & $\begin{array}{l}\text { Phospholipid-transporting } \\
\text { ATPase ABCA7 }\end{array}$ & Lipid transporter & Not described \\
\hline CCNF [26] & Cyclin F & Cell cycle regulation & Not described \\
\hline CHCHD10 [192] & $\begin{array}{l}\text { Coiled-coil-helix-coiled-coil } \\
\text { helix domain containing } 10\end{array}$ & Mitochondrial function & Not described \\
\hline CSF1R [193] & $\begin{array}{l}\text { Colony-stimulating factor } \\
1 \text { receptor }\end{array}$ & Microglial function & $\begin{array}{c}\text { Hereditary diffuse } \\
\text { leukoencephalopathy [191] }\end{array}$ \\
\hline CTSF [154] & Cathepsin F & Protein degradation & Leukoencephalopathy [191] \\
\hline CYLD [194] & $\begin{array}{l}\text { Ubiquitin carboxyl-terminal } \\
\text { hydrolase CYLD }\end{array}$ & Autophagy, neuroinflammation & $\begin{array}{l}\text { Widespread glia with } \\
\text { CYLD-immunopositivity [15] }\end{array}$ \\
\hline CYP27A1 [154] & $\begin{array}{l}\text { Cytochrome P450 family } \\
27 \text { subfamily A member } 1\end{array}$ & Cholesterol metabolism & Cerebrotendinous Xanthomatosis [191] \\
\hline LRRK2 [157] & Leucine-rich repeat kinase 2 & Lipid metabolism & $\begin{array}{c}\text { Occasional glia with } \\
\text { LRRK2-immunopositivity [149] }\end{array}$ \\
\hline OPTN [157] & Optineurin & $\begin{array}{l}\text { Autophagy, membrane } \\
\text { trafficking, cell cycle control, } \\
\text { vesicle transport, } \\
\text { NF-kB regulation }\end{array}$ & Not described \\
\hline PNF1 [157] & Profilin1 & $\begin{array}{l}\text { Regulation of actin } \\
\text { polymerisation }\end{array}$ & Not described \\
\hline PSEN1 [154] & Presenilin 1 & Proteolysis & $\begin{array}{l}\text { Increased white matter } \\
\text { hyperintensities [195] }\end{array}$ \\
\hline PSEN2 [154] & Presenilin 2 & Proteolysis & Not described \\
\hline SNCA [155] & Alpha-synuclein & $\begin{array}{l}\text { Neuroprotection, neuronal } \\
\text { differentiation, dopamine } \\
\text { biosynthesis, maintenance of } \\
\text { polysaturated fatty acids levels }\end{array}$ & $\begin{array}{l}\text { Widespread oligodendrocytic } \\
\text { inclusions in multiple system } \\
\text { atrophy [196] }\end{array}$ \\
\hline SORL1 [156] & Sortilin-related receptor 1 & $\begin{array}{l}\text { Sorting and trafficking of } \\
\text { intracellular proteins }\end{array}$ & $\begin{array}{l}\text { Lower integrity of white matter } \\
\text { tracts [197] }\end{array}$ \\
\hline SORT1 [161] & Sortilin 1 & $\begin{array}{l}\text { Protein trafficking; involved in } \\
\text { glucose and lipid metabolism. }\end{array}$ & Not described \\
\hline SQSTM1 [164] & Sequestosome/p62 & Autophagy & $\begin{array}{l}\text { Widespread oligodendroglial pTDP-43 } \\
\text { inclusions [198] }\end{array}$ \\
\hline TARDBP [199] & TAR DNA-binding protein 43 & Transcription and RNA splicing & - \\
\hline TREM2 [177] & $\begin{array}{l}\text { Triggering receptor expressed } \\
\text { on myeloid cells } 2\end{array}$ & $\begin{array}{l}\text { Activation of macrophages, } \\
\text { microglia and dendritic cell }\end{array}$ & $\begin{array}{l}\text { Nasu-Hakola disease/polycystic } \\
\text { lipomembranous osteodysplasia with } \\
\text { sclerosing leukoencephalopathy [191] }\end{array}$ \\
\hline$T Y R O B P[178]$ & $\begin{array}{l}\text { Transmembrane immune } \\
\text { signaling adaptor }\end{array}$ & $\begin{array}{l}\text { Macrophages and dendritic cells } \\
\text { activation. Microglia activation } \\
\text { in the brain }\end{array}$ & Nasu-Hakola disease [191] \\
\hline UBQLN2 [200] & Ubiquilin 2 & $\begin{array}{l}\text { Protein degradation, cell } \\
\text { cycle regulation }\end{array}$ & $\begin{array}{l}\text { Widespread demylination of white } \\
\text { matter [201] }\end{array}$ \\
\hline
\end{tabular}

\subsection{TREM2 and TYROBP}

In the brain, TREM2 is exclusively expressed in microglial cells, where it interacts with TYROBP to initiate signaling cascades that promote microglial cell activation, phagocytosis 
and microglial survival [202]. TREM2 and TYROBP variants are found in patients with polycystic lipomembranous osteodysplasia with sclerosing leukoencephalopathy (PLOSL) or Nasu-Hakola disease (NHD), an autosomal recessive hereditary disease characterized by early-onset dementia and bone cysts [203,204], concomitant with atrophy of temporal white matter and loss of myelin and axon in the brain [205], although some NHD patients with FTD-like syndromes are reported to lack bone phenotypes $[163,176,206]$. Indeed, TREM2 variants [156,163,175-177] and TYROBP variants [178] are associated with increased risk of disease in FTD patients.

Microglial cells are pivotal in remyelination by clearing myelin debris from sites of demyelination. Macrophages deficient in TREM2 were reported to have defects in the phagocytic pathways. A recent study of TREM2-deficient mice revealed cholesteryl ester accumulation in the brain and microglia, due to the transgenic mice's inability to upregulate lipid metabolism genes. This led to an impaired ability of the microglia to phagocytose an influx of cholesterol brought about by chronic demyelination [207].

\subsection{CSF1R}

CSF1R encodes the colony-stimulating factor 1 receptor, a transmembrane tyrosine kinase receptor found in mononuclear phagocytotic cells and microglia in the brain that is crucial for microglial function $[208,209]$. CSF1R variants are associated with hereditary diffuse leukoencephalopathy (HDLS) with axonal spheroids and pigmented glia (ALSP) [193], bvFTD [37], CBS, AD, multiple sclerosis, leukoencephalopathy (CADASIL) and PD [193]. Heterozygous CSF1R variants were identified in patients with presentations similar to that of parkinsonism [210] and bvFTD [173,174]. Indeed, it has been postulated that $26.9 \%$ of histopathologically confirmed ALSP cases would have met the diagnostic criteria for "possible bvFTD", while 11.5\% could be diagnosed as "probable bvFTD" [211].

Neuropathologically, CSF1R-related leukoencephalopathy resulted in patchy white matter degeneration, featuring atrophy and confluent bilateral white matter hyperintensities, accompanied by loss of myelin and axons, presence of neuroaxonal spheroids and lipid-laden and pigmented macrophages $[208,212,213]$ that were observed 6 years prior to symptoms onset [208].

\subsection{CYP27A1}

CYP27A1 encodes sterol 27-hydroxylase, a mitochondrial cytochrome p450 oxidase involved in cholesterol metabolism and the synthesis of bile acids. Homozygous or compound heterozygous mutations in CYP27A1 lead to cerebrotendinous xanthomatosis (CTX), a lipid storage disorder associated with a diverse range of neurological dysfunctions [214]. Of note, a homozygous mutation in CYP27A1 was reported in a patient with clinical FTD, but without the typical CTX neuroimaging changes when examined using MRI [154]. Critically, the disease can be treated with bile salts prior to symptom onset [214], making it imperative to promptly perform a genetic diagnosis of mutation carriers and families.

\section{Implications for Novel FTD Therapeutics}

The consistent changes in white matter observed in FTD brains, as well as the genetic overlap between FTD and leukoencephalopathies/leukodystrophies, strongly support the hypothesis that therapies targeting white matter integrity, or remyelination, would be efficacious. Both processes of myelination and re-myelination after injury are mediated by oligodendrocytes [215]. The mature cells are derived from oligodendrocyte precursor cells (OPCs), which switch from a quiescent state to a regeneration phenotype in response to various biological signals. These include neuronal activity [216] and the expression of growth factors that drive OPC proliferation and promote survival [217]. This knowledge can be exploited to induce remyelination in the following scenarios. 


\subsection{Novel Targets for Gene-Specific or Pharmacological Intervention}

The genetic overlap between leukoencephalopathies/leukodystrophies and FTD has opened up exciting opportunities for FTD therapeutics. TMEM106B is one of the genes that straddle the genetic spectrum of FTD and leukodystrophy, and knock-down of its expression appears to have a protective role in myelination [190]. Genetic ablation of TMEM106B expression was found to be effective in rescuing the FTD-like phenotypes in a transgenic mouse model carrying the GRN [218], but not the C9orf72, transgene [219]. However, this could reflect the differential white matter changes in C9orf 72 mutation carriers compared with GRN mutation carriers [82]. The concept of brain-region specificity can be exploited by pharmacological agents. BLZ945, an inhibitor of CSF1R kinase, was shown to enhance remyelination in the cortex/striatum [220], while PLX3397 increased myelination in the corpus callosum [221]. Recently, it was shown that TREM2 activation via agonistic antibodies accelerated microglial removal of myelin debris and enhanced remyelination [222]; also, prophylactic treatment with the compound was reported to prevent demyelination in mice [220].

\subsection{Transcranial Magnetic Stimulation for Sporadic and Genetic Forms of FTD}

Transcranial magnetic stimulation (TMS) is a non-invasive form of neural stimulation that applies local magnetic fields to generate electric currents in the brain, leading to an increase in neuronal activity [223] that is known to stimulate myelination [224]. TMS has consistently been shown to enhance myelination and secretion of neurotrophic factors in oligodendrocytes [225], to accelerate differentiation of an oligodendrocyte precursor cell line [226], to promote oligodendrocyte survival and differentiation in adult mouse brains [227] and to inhibit demyelination and increase neuronal and axonal survival [228].

Currently, clinical applications of TMS include diagnosis, monitoring and treatment of neurodegenerative diseases such as epilepsy [229], PD [230], AD [231] and ALS [232], as well as neuropsychiatric disorders including depression [233,234], schizophrenia $[235,236]$ and bipolar disorder [237], without serious adverse effects $[238,239]$. Thus, the demonstrated effect of TMS on remyelination, together with its relative safety in clinical applications, makes TMS an ideal candidate for remyelination therapy in leukodystrophy/encephalopathy/FTD. Indeed, a randomized control trial of 70 FTD cases, of which 22 were GRN, MAPT and C9orf72 mutation carriers, demonstrated efficacy, with significant increase of intracortical connectivity and improvement in clinical scores and behavioral disturbances in both symptomatic patients and pre-symptomatic mutation carriers [240].

\section{Conclusions}

Recent advances in sequencing technology have enabled the rapid discovery of novel FTD genes that enhance our understanding of this complex disease. While previous investigation into the pathogenesis of causal FTD genes has focused on their impact on neuronal functions, GWAS and NGS have revealed a number of novel FTD genes that affect both neurons and glia, whose mutations are associated with white matter abnormalities in carriers. In particular, our review highlights the extensive clinical and genetic overlap between FTD and leukoencephalopathy/leukodystrophy. This, in turn, has implications for pharmacological and non-pharmacological strategies to enhance oligodendrocyte numbers and the myelination process.

Author Contributions: Conceptualization, J.B.K. and H.C.L.; writing—original draft preparation, H.C.L.; writing - review and editing J.B.K.; supervision, J.B.K.; funding acquisition, J.B.K. All authors have read and agreed to the published version of the manuscript.

Funding: This research was funded by Australian National Health and Medical Research Council GNT1163249, GNT1140708 and GNT1095127.

Institutional Review Board Statement: Ethical review and approval were waived for this study, due to nature of review article only synthesizing published literature. 
Informed Consent Statement: Patient consent was waived due to due to nature of review article only synthesizing published literature.

Acknowledgments: We thank Carol Dobson-Stone (University of Sydney, Australia) for her help in the preparation of the manuscript.

Conflicts of Interest: The authors declare no conflict of interest.

\section{References}

1. Rascovsky, K.; Hodges, J.R.; Knopman, D.; Mendez, M.F.; Kramer, J.H.; Neuhaus, J.; Van Swieten, J.C.; Seelaar, H.; Dopper, E.G.; Onyike, C.U.; et al. Sensitivity of revised diagnostic criteria for the behavioural variant of frontotemporal dementia. Brain 2011, 134, 2456. [CrossRef]

2. Gorno-Tempini, M.L.; Hillis, A.E.; Weintraub, S.; Kertesz, A.; Mendez, M.; Cappa, S.F.; Ogar, J.M.; Rohrer, J.D.; Black, S.; Boeve, B.F.; et al. Classification of primary progressive aphasia and its variants. Neurology 2011, 76, 1006-1014. [CrossRef]

3. Rohrer, J.D.; Guerreiro, R.; Vandrovcova, J.; Uphill, J.; Reiman, D.; Beck, J.; Isaacs, A.M.; Authier, A.; Ferrari, R.; Fox, N.C.; et al. The heritability and genetics of frontotemporal lobar degeneration. Neurology 2009, 73, 1451-1456. [CrossRef] [PubMed]

4. Hutton, M.; Lendon, C.L.; Rizzu, P.; Baker, M.; Froelich, S.; Houlden, H.; Pickering-Brown, S.; Chakraverty, S.; Isaacs, A.; Grover, A.; et al. Association of missense and 5'-splice-site mutations in tau with the inherited dementia FTDP-17. Nature 1998, 393, 702-705. [CrossRef] [PubMed]

5. Baker, M.; Mackenzie, I.R.; Pickering-Brown, S.M.; Gass, J.; Rademakers, R.; Lindholm, C.; Snowden, J.; Adamson, J.; Sadovnick, A.D.; Rollinson, S.; et al. Mutations in progranulin cause tau-negative frontotemporal dementia linked to chromosome 17. Nature 2006, 442, 916-919. [CrossRef]

6. Cruts, M.; Gijselinck, I.; Van der Zee, J.; Engelborghs, S.; Wils, H.; Pirici, D.; Rademakers, R.; Vandenberghe, R.; Dermaut, B.; Martin, J.J.; et al. Null mutations in progranulin cause ubiquitin-positive frontotemporal dementia linked to chromosome $17 \mathrm{q} 21$. Nature 2006, 442, 920-924. [CrossRef]

7. DeJesus-Hernandez, M.; Mackenzie, I.R.; Boeve, B.F.; Boxer, A.L.; Baker, M.; Rutherford, N.J.; Nicholson, A.M.; Finch, N.A.; Flynn, H.; Adamson, J.; et al. Expanded GGGGCC hexanucleotide repeat in noncoding region of C9ORF72 causes chromosome 9p-linked FTD and ALS. Neuron 2011, 72, 245-256. [CrossRef]

8. Renton, A.E.; Majounie, E.; Waite, A.; Simon-Sanchez, J.; Rollinson, S.; Gibbs, J.R.; Schymick, J.C.; Laaksovirta, H.; Van Swieten, J.C.; Myllykangas, L.; et al. A hexanucleotide repeat expansion in C9ORF72 is the cause of chromosome 9p21-linked ALS-FTD. Neuron 2011, 72, 257-268. [CrossRef]

9. Loy, C.T.; Schofield, P.R.; Turner, A.M.; Kwok, J.B. Genetics of dementia. Lancet 2014, 383, 828-840. [CrossRef]

10. Bott, N.T.; Radke, A.; Stephens, M.L.; Kramer, J.H. Frontotemporal dementia: Diagnosis, deficits and management. Neurodegener. Dis. Manag. 2014, 4, 439-454. [CrossRef] [PubMed]

11. De Majo, M.; Topp, S.D.; Smith, B.N.; Nishimura, A.L.; Chen, H.J.; Gkazi, A.S.; Miller, J.; Wong, C.H.; Vance, C.; Baas, F.; et al. ALS-associated missense and nonsense TBK1 mutations can both cause loss of kinase function. Neurobiol. Aging 2018, 71, e1-e10. [CrossRef]

12. Gijselinck, I.; Van Mossevelde, S.; Van der Zee, J.; Sieben, A.; Philtjens, S.; Heeman, B.; Engelborghs, S.; Van den Bulcke, M.; De Baets, G.; Baumer, V.; et al. Loss of TBK1 is a frequent cause of frontotemporal dementia in a Belgian cohort. Neurology 2015, 85, 2116-2125. [CrossRef]

13. Greaves, C.V.; Rohrer, J.D. An update on genetic frontotemporal dementia. J. Neurol. 2019, 266, 2075-2086. [CrossRef]

14. Goldman, J.S.; Van Deerlin, V.M. Alzheimer's Disease and Frontotemporal Dementia: The Current State of Genetics and Genetic Testing Since the Advent of Next-Generation Sequencing. Mol. Diagn. Ther. 2018, 22, 505-513. [CrossRef] [PubMed]

15. Dobson-Stone, C.; Hallupp, M.; Shahheydari, H.; Ragagnin, A.M.G.; Chatterton, Z.; Carew-Jones, F.; Shepherd, C.E.; Stefen, H.; Paric, E.; Fath, T.; et al. CYLD is a causative gene for frontotemporal dementia-amyotrophic lateral sclerosis. Brain 2020, 143, 783-799. [CrossRef] [PubMed]

16. Oyston, L.J.; Chatterton, Z.; Hallupp, M.; Rajan, N.; Kwok, J.B.; Dobson-Stone, C. Reply: CYLD variants in frontotemporal dementia associated with severe memory impairment in a Portuguese cohort. Brain 2020, 143, e68. [CrossRef] [PubMed]

17. Chen, Y.; Landin-Romero, R.; Kumfor, F.; Irish, M.; Hodges, J.R.; Piguet, O. Cerebellar structural connectivity and contributions to cognition in frontotemporal dementias. Cortex 2020, 129, 57-67. [CrossRef]

18. Hasegawa, M.; Smith, M.J.; Iijima, M.; Tabira, T.; Goedert, M. FTDP-17 mutations N279K and S305N in tau produce increased splicing of exon 10. FEBS Lett. 1999, 443, 93-96. [CrossRef]

19. Hong, M.; Zhukareva, V.; Vogelsberg-Ragaglia, V.; Wszolek, Z.; Reed, L.; Miller, B.I.; Geschwind, D.H.; Bird, T.D.; McKeel, D.; Goate, A.; et al. Mutation-specific functional impairments in distinct tau isoforms of hereditary FTDP-17. Science 1998, 282, 1914-1917. [CrossRef]

20. Josephs, K.A.; Hodges, J.R.; Snowden, J.S.; Mackenzie, I.R.; Neumann, M.; Mann, D.M.; Dickson, D.W. Neuropathological background of phenotypical variability in frontotemporal dementia. Acta Neuropathol. 2011, 122, 137-153. [CrossRef]

21. Forrest, S.L.; Halliday, G.M.; Shepherd, C.E.; Kwok, J.B.; Hallupp, M.; Kril, J.J. Are mutations in MAPT associated with GGT type III? Neuropathol. Appl. Neurobiol. 2020, 46, 406-409. [CrossRef] 
22. Boeve, B.F.; Hutton, M. Refining frontotemporal dementia with parkinsonism linked to chromosome 17: Introducing FTDP-17 (MAPT) and FTDP-17 (PGRN). Arch. Neurol. 2008, 65, 460-464. [CrossRef]

23. Rohrer, J.D.; Warren, J.D. Phenotypic signatures of genetic frontotemporal dementia. Curr. Opin. Neurol. 2011, $24,542-549$. [CrossRef] [PubMed]

24. Pickering-Brown, S.M.; Rollinson, S.; Du Plessis, D.; Morrison, K.E.; Varma, A.; Richardson, A.M.; Neary, D.; Snowden, J.S.; Mann, D.M. Frequency and clinical characteristics of progranulin mutation carriers in the Manchester frontotemporal lobar degeneration cohort: Comparison with patients with MAPT and no known mutations. Brain 2008, 131, 721-731. [CrossRef]

25. Rohrer, J.D.; Ridgway, G.R.; Modat, M.; Ourselin, S.; Mead, S.; Fox, N.C.; Rossor, M.N.; Warren, J.D. Distinct profiles of brain atrophy in frontotemporal lobar degeneration caused by progranulin and tau mutations. Neuroimage 2010, 53, 1070-1076. [CrossRef]

26. Whitwell, J.L.; Avula, R.; Senjem, M.L.; Kantarci, K.; Weigand, S.D.; Samikoglu, A.; Edmonson, H.A.; Vemuri, P.; Knopman, D.S.; Boeve, B.F.; et al. Gray and white matter water diffusion in the syndromic variants of frontotemporal dementia. Neurology 2010, 74, 1279-1287. [CrossRef]

27. Bang, J.; Spina, S.; Miller, B.L. Frontotemporal dementia. Lancet 2015, 386, 1672-1682. [CrossRef]

28. Mackenzie, I.R.; Rademakers, R. The role of transactive response DNA-binding protein-43 in amyotrophic lateral sclerosis and frontotemporal dementia. Curr. Opin. Neurol. 2008, 21, 693-700. [CrossRef]

29. Mackenzie, I.R.; Neumann, M.; Cairns, N.J.; Munoz, D.G.; Isaacs, A.M. Novel types of frontotemporal lobar degeneration: Beyond tau and TDP-43. J. Mol. Neurosci. 2011, 45, 402-408. [CrossRef]

30. Tan, R.H.; Shepherd, C.E.; Kril, J.J.; McCann, H.; McGeachie, A.; McGinley, C.; Affleck, A.; Halliday, G.M. Classification of FTLD-TDP cases into pathological subtypes using antibodies against phosphorylated and non-phosphorylated TDP43. Acta Neuropathol. Commun. 2013, 1, 33. [CrossRef] [PubMed]

31. Van Langenhove, T.; Van der Zee, J.; Gijselinck, I.; Engelborghs, S.; Vandenberghe, R.; Vandenbulcke, M.; De Bleecker, J.; Sieben, A.; Versijpt, J.; Ivanoiu, A.; et al. Distinct clinical characteristics of C9orf72 expansion carriers compared with GRN, MAPT, and nonmutation carriers in a Flanders-Belgian FTLD cohort. JAMA Neurol. 2013, 70, 365-373. [CrossRef] [PubMed]

32. Van Mossevelde, S.; Van der Zee, J.; Gijselinck, I.; Engelborghs, S.; Sieben, A.; Van Langenhove, T.; De Bleecker, J.; Baets, J.; Vandenbulcke, M.; Van Laere, K.; et al. Clinical features of TBK1 carriers compared with C9orf72, GRN and non-mutation carriers in a Belgian cohort. Brain 2016, 139, 452-467. [CrossRef]

33. Mahoney, C.J.; Downey, L.E.; Ridgway, G.R.; Beck, J.; Clegg, S.; Blair, M.; Finnegan, S.; Leung, K.K.; Yeatman, T.; Golden, H.; et al. Longitudinal neuroimaging and neuropsychological profiles of frontotemporal dementia with C9ORF72 expansions. Alzheimer's Res. Ther. 2012, 4, 41. [CrossRef]

34. Majounie, E.; Renton, A.E.; Mok, K.; Dopper, E.G.; Waite, A.; Rollinson, S.; Chio, A.; Restagno, G.; Nicolaou, N.; SimonSanchez, J.; et al. Frequency of the C9orf72 hexanucleotide repeat expansion in patients with amyotrophic lateral sclerosis and frontotemporal dementia: A cross-sectional study. Lancet Neurol. 2012, 11, 323-330. [CrossRef]

35. He, J.; Tang, L.; Benyamin, B.; Shah, S.; Hemani, G.; Liu, R.; Ye, S.; Liu, X.; Ma, Y.; Zhang, H.; et al. C9orf72 hexanucleotide repeat expansions in Chinese sporadic amyotrophic lateral sclerosis. Neurobiol. Aging 2015, 36, 1-8. [CrossRef]

36. Ogaki, K.; Li, Y.; Takanashi, M.; Ishikawa, K.; Kobayashi, T.; Nonaka, T.; Hasegawa, M.; Kishi, M.; Yoshino, H.; Funayama, M.; et al. Analyses of the MAPT, PGRN, and C9orf72 mutations in Japanese patients with FTLD, PSP, and CBS. Parkinsonism Relat. Disord. 2013, 19, 15-20. [CrossRef]

37. Kim, E.J.; Kim, Y.E.; Jang, J.H.; Cho, E.H.; Na, D.L.; Seo, S.W.; Jung, N.Y.; Jeong, J.H.; Kwon, J.C.; Park, K.H.; et al. Analysis of frontotemporal dementia, amyotrophic lateral sclerosis, and other dementia-related genes in 107 Korean patients with frontotemporal dementia. Neurobiol. Aging 2018, 72, 186. [CrossRef] [PubMed]

38. Dobson-Stone, C.; Hallupp, M.; Bartley, L.; Shepherd, C.E.; Halliday, G.M.; Schofield, P.R.; Hodges, J.R.; Kwok, J.B. C9ORF72 repeat expansion in clinical and neuropathologic frontotemporal dementia cohorts. Neurology 2012, 79, 995-1001. [CrossRef]

39. Dobson-Stone, C.; Hallupp, M.; Loy, C.T.; Thompson, E.M.; Haan, E.; Sue, C.M.; Panegyres, P.K.; Razquin, C.; Seijo-Martinez, M.; Rene, R.; et al. C9ORF72 repeat expansion in Australian and Spanish frontotemporal dementia patients. PLoS ONE 2013, 8, e56899. [CrossRef] [PubMed]

40. Mackenzie, I.R.; Arzberger, T.; Kremmer, E.; Troost, D.; Lorenzl, S.; Mori, K.; Weng, S.M.; Haass, C.; Kretzschmar, H.A.; Edbauer, D.; et al. Dipeptide repeat protein pathology in C9ORF72 mutation cases: Clinico-pathological correlations. Acta Neuropathol. 2013, 126, 859-879. [CrossRef] [PubMed]

41. Mann, D.M.; Rollinson, S.; Robinson, A.; Bennion Callister, J.; Thompson, J.C.; Snowden, J.S.; Gendron, T.; Petrucelli, L.; Masuda-Suzukake, M.; Hasegawa, M.; et al. Dipeptide repeat proteins are present in the p62 positive inclusions in patients with frontotemporal lobar degeneration and motor neurone disease associated with expansions in C9ORF72. Acta Neuropathol. Commun. 2013, 1, 68. [CrossRef]

42. Snowden, J.S.; Rollinson, S.; Thompson, J.C.; Harris, J.M.; Stopford, C.L.; Richardson, A.M.; Jones, M.; Gerhard, A.; Davidson, Y.S.; Robinson, A.; et al. Distinct clinical and pathological characteristics of frontotemporal dementia associated with C9ORF72 mutations. Brain 2012, 135, 693-708. [CrossRef]

43. Lee, S.M.; Asress, S.; Hales, C.M.; Gearing, M.; Vizcarra, J.C.; Fournier, C.N.; Gutman, D.A.; Chin, L.S.; Li, L.; Glass, J.D. TDP-43 cytoplasmic inclusion formation is disrupted in C9orf72-associated amyotrophic lateral sclerosis/frontotemporal lobar degeneration. Brain Commun. 2019, 1, 14. [CrossRef] 
44. Cook, C.N.; Wu, Y.; Odeh, H.M.; Gendron, T.F.; Jansen-West, K.; Del Rosso, G.; Yue, M.; Jiang, P.; Gomes, E.; Tong, J.; et al. C9orf72 poly (GR) aggregation induces TDP-43 proteinopathy. Sci. Transl. Med. 2020, 12, 559. [CrossRef]

45. Van der Zee, J.; Gijselinck, I.; Van Mossevelde, S.; Perrone, F.; Dillen, L.; Heeman, B.; Baumer, V.; Engelborghs, S.; De Bleecker, J.; Baets, J.; et al. TBK1 Mutation Spectrum in an Extended European Patient Cohort with Frontotemporal Dementia and Amyotrophic Lateral Sclerosis. Hum. Mutat. 2017, 38, 297-309. [CrossRef]

46. Lamb, R.; Rohrer, J.D.; Real, R.; Lubbe, S.J.; Waite, A.J.; Blake, D.J.; Walters, R.J.; Lashley, T.; Revesz, T.; Holton, J.L.; et al. A novel TBK1 mutation in a family with diverse frontotemporal dementia spectrum disorders. Cold Spring Harb. Mol. Case Stud. 2019, 5, 3. [CrossRef] [PubMed]

47. Koriath, C.A.; Bocchetta, M.; Brotherhood, E.; Woollacott, I.O.; Norsworthy, P.; Simon-Sanchez, J.; Blauwendraat, C.; Dick, K.M.; Gordon, E.; Harding, S.R.; et al. The clinical, neuroanatomical, and neuropathologic phenotype of TBK1-associated frontotemporal dementia: A longitudinal case report. Alzheimer's Dement. 2017, 6, 75-81. [CrossRef] [PubMed]

48. Hirsch-Reinshagen, V.; Alfaify, O.A.; Hsiung, G.R.; Pottier, C.; Baker, M.; Perkerson, R.B., 3rd; Rademakers, R.; Briemberg, H.; Foti, D.J.; Mackenzie, I.R. Clinicopathologic correlations in a family with a TBK1 mutation presenting as primary progressive aphasia and primary lateral sclerosis. Amyotroph. Lateral Scler. Frontotemporal. Degener. 2019, 20, 568-575. [CrossRef]

49. Mackenzie, I.R. The neuropathology and clinical phenotype of FTD with progranulin mutations. Acta Neuropathol. 2007, 114, 49-54. [CrossRef]

50. Mackenzie, I.R.; Baker, M.; Pickering-Brown, S.; Hsiung, G.Y.; Lindholm, C.; Dwosh, E.; Gass, J.; Cannon, A.; Rademakers, R.; Hutton, M.; et al. The neuropathology of frontotemporal lobar degeneration caused by mutations in the progranulin gene. Brain 2006, 129, 3081-3090. [CrossRef] [PubMed]

51. Hosokawa, M.; Kondo, H.; Serrano, G.E.; Beach, T.G.; Robinson, A.C.; Mann, D.M.; Akiyama, H.; Hasegawa, M.; Arai, T. Accumulation of multiple neurodegenerative disease-related proteins in familial frontotemporal lobar degeneration associated with granulin mutation. Sci. Rep. 2017, 7, 1513. [CrossRef]

52. Zhang, Y.J.; Xu, Y.F.; Dickey, C.A.; Buratti, E.; Baralle, F.; Bailey, R.; Pickering-Brown, S.; Dickson, D.; Petrucelli, L. Progranulin mediates caspase-dependent cleavage of TAR DNA binding protein-43. J. Neurosci. 2007, 27, 10530-10534. [CrossRef]

53. Hu, F.; Padukkavidana, T.; Vaegter, C.B.; Brady, O.A.; Zheng, Y.; Mackenzie, I.R.; Feldman, H.H.; Nykjaer, A.; Strittmatter, S.M. Sortilin-mediated endocytosis determines levels of the frontotemporal dementia protein, progranulin. Neuron 2010, 68, 654-667. [CrossRef] [PubMed]

54. Chang, M.C.; Srinivasan, K.; Friedman, B.A.; Suto, E.; Modrusan, Z.; Lee, W.P.; Kaminker, J.S.; Hansen, D.V.; Sheng, M. Progranulin deficiency causes impairment of autophagy and TDP-43 accumulation. J. Exp. Med. 2017, 214, 2611-2628. [CrossRef]

55. Beck, J.; Rohrer, J.D.; Campbell, T.; Isaacs, A.; Morrison, K.E.; Goodall, E.F.; Warrington, E.K.; Stevens, J.; Revesz, T.; Holton, J.; et al. A distinct clinical, neuropsychological and radiological phenotype is associated with progranulin gene mutations in a large UK series. Brain 2008, 131, 706-720. [CrossRef]

56. Boeve, B.F.; Baker, M.; Dickson, D.W.; Parisi, J.E.; Giannini, C.; Josephs, K.A.; Hutton, M.; Pickering-Brown, S.M.; Rademakers, R.; Tang-Wai, D.; et al. Frontotemporal dementia and parkinsonism associated with the IVS1+1G->A mutation in progranulin: A clinicopathologic study. Brain 2006, 129, 3103-3114. [CrossRef]

57. Leverenz, J.B.; Yu, C.E.; Montine, T.J.; Steinbart, E.; Bekris, L.M.; Zabetian, C.; Kwong, L.K.; Lee, V.M.; Schellenberg, G.D.; Bird, T.D. A novel progranulin mutation associated with variable clinical presentation and tau, TDP43 and alpha-synuclein pathology. Brain 2007, 130, 1360-1374. [CrossRef] [PubMed]

58. Petkau, T.L.; Leavitt, B.R. Progranulin in neurodegenerative disease. Trends Neurosci. 2014, 37, 388-398. [CrossRef] [PubMed]

59. Van Swieten, J.C.; Heutink, P. Mutations in progranulin (GRN) within the spectrum of clinical and pathological phenotypes of frontotemporal dementia. Lancet Neurol. 2008, 7, 965-974. [CrossRef]

60. Le Ber, I.; Camuzat, A.; Hannequin, D.; Pasquier, F.; Guedj, E.; Rovelet-Lecrux, A.; Hahn-Barma, V.; Van der Zee, J.; Clot, F.; Bakchine, S.; et al. Phenotype variability in progranulin mutation carriers: A clinical, neuropsychological, imaging and genetic study. Brain 2008, 131, 732-746. [CrossRef]

61. Mackenzie, I.R.; Neumann, M. Molecular neuropathology of frontotemporal dementia: Insights into disease mechanisms from postmortem studies. J. Neurochem. 2016, 138, 54-70. [CrossRef]

62. Paternico, D.; Premi, E.; Gazzina, S.; Cosseddu, M.; Alberici, A.; Archetti, S.; Cotelli, M.S.; Micheli, A.; Turla, M.; Gasparotti, R.; et al. White matter hyperintensities characterize monogenic frontotemporal dementia with granulin mutations. Neurobiol. Aging 2016, 38, 176-180. [CrossRef] [PubMed]

63. Sudre, C.H.; Bocchetta, M.; Heller, C.; Convery, R.; Neason, M.; Moore, K.M.; Cash, D.M.; Thomas, D.L.; Woollacott, I.O.C.; Foiani, M.; et al. White matter hyperintensities in progranulin-associated frontotemporal dementia: A longitudinal GENFI study. Neuroimage Clin. 2019, 24, 102077. [CrossRef]

64. Woollacott, I.O.C.; Bocchetta, M.; Sudre, C.H.; Ridha, B.H.; Strand, C.; Courtney, R.; Ourselin, S.; Cardoso, M.J.; Warren, J.D.; Rossor, M.N.; et al. Pathological correlates of white matter hyperintensities in a case of progranulin mutation associated frontotemporal dementia. Neurocase 2018, 24, 166-174. [CrossRef] [PubMed]

65. Sudre, C.H.; Bocchetta, M.; Cash, D.; Thomas, D.L.; Woollacott, I.; Dick, K.M.; Van Swieten, J.; Borroni, B.; Galimberti, D.; Masellis, M.; et al. White matter hyperintensities are seen only in GRN mutation carriers in the GENFI cohort. Neuroimage Clin. 2017, 15, 171-180. [CrossRef] [PubMed] 
66. Caroppo, P.; Le Ber, I.; Camuzat, A.; Clot, F.; Naccache, L.; Lamari, F.; De Septenville, A.; Bertrand, A.; Belliard, S.; Hannequin, D.; et al. Extensive white matter involvement in patients with frontotemporal lobar degeneration: Think progranulin. JAMA Neurol. 2014, 71, 1562-1566. [CrossRef]

67. Elahi, F.M.; Marx, G.; Cobigo, Y.; Staffaroni, A.M.; Kornak, J.; Tosun, D.; Boxer, A.L.; Kramer, J.H.; Miller, B.L.; Rosen, H.J. Longitudinal white matter change in frontotemporal dementia subtypes and sporadic late onset Alzheimer's disease. Neuroimage Clin. 2017, 16, 595-603. [CrossRef] [PubMed]

68. Frings, L.; Yew, B.; Flanagan, E.; Lam, B.Y.; Hull, M.; Huppertz, H.J.; Hodges, J.R.; Hornberger, M. Longitudinal grey and white matter changes in frontotemporal dementia and Alzheimer's disease. PLoS ONE 2014, 9, e90814. [CrossRef]

69. Zhang, Y.; Schuff, N.; Du, A.T.; Rosen, H.J.; Kramer, J.H.; Gorno-Tempini, M.L.; Miller, B.L.; Weiner, M.W. White matter damage in frontotemporal dementia and Alzheimer's disease measured by diffusion MRI. Brain 2009, 132, 2579-2592. [CrossRef]

70. Mahoney, C.J.; Simpson, I.J.; Nicholas, J.M.; Fletcher, P.D.; Downey, L.E.; Golden, H.L.; Clark, C.N.; Schmitz, N.; Rohrer, J.D.; Schott, J.M.; et al. Longitudinal diffusion tensor imaging in frontotemporal dementia. Ann. Neurol. 2015, 77, 33-46. [CrossRef]

71. Galantucci, S.; Tartaglia, M.C.; Wilson, S.M.; Henry, M.L.; Filippi, M.; Agosta, F.; Dronkers, N.F.; Henry, R.G.; Ogar, J.M.; Miller, B.L.; et al. White matter damage in primary progressive aphasias: A diffusion tensor tractography study. Brain 2011, 134, 3011-3029. [CrossRef]

72. Acosta-Cabronero, J.; Patterson, K.; Fryer, T.D.; Hodges, J.R.; Pengas, G.; Williams, G.B.; Nestor, P.J. Atrophy, hypometabolism and white matter abnormalities in semantic dementia tell a coherent story. Brain 2011, 134, 2025-2035. [CrossRef] [PubMed]

73. Agosta, F.; Galantucci, S.; Svetel, M.; Lukic, M.J.; Copetti, M.; Davidovic, K.; Tomic, A.; Spinelli, E.G.; Kostic, V.S.; Filippi, M. Clinical, cognitive, and behavioural correlates of white matter damage in progressive supranuclear palsy. J. Neurol. 2014, 261, 913-924. [CrossRef] [PubMed]

74. Borroni, B.; Brambati, S.M.; Agosti, C.; Gipponi, S.; Bellelli, G.; Gasparotti, R.; Garibotto, V.; Di Luca, M.; Scifo, P.; Perani, D.; et al. Evidence of white matter changes on diffusion tensor imaging in frontotemporal dementia. Arch. Neurol. 2007, 64, $246-251$. [CrossRef]

75. Matsuo, K.; Mizuno, T.; Yamada, K.; Akazawa, K.; Kasai, T.; Kondo, M.; Mori, S.; Nishimura, T.; Nakagawa, M. Cerebral white matter damage in frontotemporal dementia assessed by diffusion tensor tractography. Neuroradiology 2008, 50, 605-611. [CrossRef]

76. Schwindt, G.C.; Graham, N.L.; Rochon, E.; Tang-Wai, D.F.; Lobaugh, N.J.; Chow, T.W.; Black, S.E. Whole-brain white matter disruption in semantic and nonfluent variants of primary progressive aphasia. Hum. Brain Mapp. 2013, 34, 973-984. [CrossRef]

77. Daianu, M.; Mendez, M.F.; Baboyan, V.G.; Jin, Y.; Melrose, R.J.; Jimenez, E.E.; Thompson, P.M. An advanced white matter tract analysis in frontotemporal dementia and early-onset Alzheimer's disease. Brain Imaging Behav. 2016, 10, 1038-1053. [CrossRef]

78. Fields, R.D. White matter in learning, cognition and psychiatric disorders. Trends Neurosci. 2008, 31, 361-370. [CrossRef]

79. Filley, C.M.; Fields, R.D. White matter and cognition: Making the connection. J. Neurophysiol. 2016, 116, 2093-2104. [CrossRef] [PubMed]

80. Olsen, A.S.B.; Faergeman, N.J. Sphingolipids: Membrane microdomains in brain development, function and neurological diseases. Open Biol. 2017, 7, 5. [CrossRef]

81. Mahoney, C.J.; Ridgway, G.R.; Malone, I.B.; Downey, L.E.; Beck, J.; Kinnunen, K.M.; Schmitz, N.; Golden, H.L.; Rohrer, J.D.; Schott, J.M.; et al. Profiles of white matter tract pathology in frontotemporal dementia. Hum. Brain Mapp. 2014, 35, 4163-4179. [CrossRef]

82. Jiskoot, L.C.; Bocchetta, M.; Nicholas, J.M.; Cash, D.M.; Thomas, D.; Modat, M.; Ourselin, S.; Rombouts, S.; Dopper, E.G.P.; Meeter, L.H.; et al. Presymptomatic white matter integrity loss in familial frontotemporal dementia in the GENFI cohort: A cross-sectional diffusion tensor imaging study. Ann. Clin. Transl. Neurol. 2018, 5, 1025-1036. [CrossRef] [PubMed]

83. Panman, J.L.; Jiskoot, L.C.; Bouts, M.; Meeter, L.H.H.; Van der Ende, E.L.; Poos, J.M.; Feis, R.A.; Kievit, A.J.A.; Van Minkelen, R.; Dopper, E.G.P.; et al. Gray and white matter changes in presymptomatic genetic frontotemporal dementia: A longitudinal MRI study. Neurobiol. Aging 2019, 76, 115-124. [CrossRef] [PubMed]

84. Rohrer, J.D.; Nicholas, J.M.; Cash, D.M.; van Swieten, J.; Dopper, E.; Jiskoot, L.; Van Minkelen, R.; Rombouts, S.A.; Cardoso, M.J.; Clegg, S.; et al. Presymptomatic cognitive and neuroanatomical changes in genetic frontotemporal dementia in the Genetic Frontotemporal dementia Initiative (GENFI) study: A cross-sectional analysis. Lancet Neurol. 2015, 14, 253-262. [CrossRef]

85. Olm, C.A.; McMillan, C.T.; Irwin, D.J.; Van Deerlin, V.M.; Cook, P.A.; Gee, J.C.; Grossman, M. Longitudinal structural gray matter and white matter MRI changes in presymptomatic progranulin mutation carriers. Neuroimage Clin. 2018, 19, 497-506. [CrossRef]

86. Chao, L.L.; Schuff, N.; Clevenger, E.M.; Mueller, S.G.; Rosen, H.J.; Gorno-Tempini, M.L.; Kramer, J.H.; Miller, B.L.; Weiner, M.W. Patterns of white matter atrophy in frontotemporal lobar degeneration. Arch. Neurol. 2007, 64, 1619-1624. [CrossRef]

87. Agosta, F.; Scola, E.; Canu, E.; Marcone, A.; Magnani, G.; Sarro, L.; Copetti, M.; Caso, F.; Cerami, C.; Comi, G.; et al. White matter damage in frontotemporal lobar degeneration spectrum. Cereb. Cortex 2012, 22, 2705-2714. [CrossRef] [PubMed]

88. Lansdall, C.J.; Coyle-Gilchrist, I.T.S.; Jones, P.S.; Vazquez Rodriguez, P.; Wilcox, A.; Wehmann, E.; Dick, K.M.; Robbins, T.W.; Rowe, J.B. White matter change with apathy and impulsivity in frontotemporal lobar degeneration syndromes. Neurology 2018, 90, e1066-e1076. [CrossRef] [PubMed]

89. Tovar-Moll, F.; De Oliveira-Souza, R.; Bramati, I.E.; Zahn, R.; Cavanagh, A.; Tierney, M.; Moll, J.; Grafman, J. White matter tract damage in the behavioral variant of frontotemporal and corticobasal dementia syndromes. PLoS ONE 2014, 9, e102656. [CrossRef] 
90. Gopalakrishnan, G.; Awasthi, A.; Belkaid, W.; De Faria, O., Jr.; Liazoghli, D.; Colman, D.R.; Dhaunchak, A.S. Lipidome and proteome map of myelin membranes. J. Neurosci. Res. 2013, 91, 321-334. [CrossRef]

91. Cermenati, G.; Mitro, N.; Audano, M.; Melcangi, R.C.; Crestani, M.; De Fabiani, E.; Caruso, D. Lipids in the nervous system: From biochemistry and molecular biology to patho-physiology. Biochim. Biophys. Acta 2015, 1851, 51-60. [CrossRef]

92. Korade, Z.; Kenworthy, A.K. Lipid rafts, cholesterol, and the brain. Neuropharmacology 2008, 55, 1265-1273. [CrossRef] [PubMed]

93. Jana, A.; Hogan, E.L.; Pahan, K. Ceramide and neurodegeneration: Susceptibility of neurons and oligodendrocytes to cell damage and death. J. Neurol. Sci. 2009, 278, 5-15. [CrossRef] [PubMed]

94. Soderberg, M.; Edlund, C.; Alafuzoff, I.; Kristensson, K.; Dallner, G. Lipid composition in different regions of the brain in Alzheimer's disease/senile dementia of Alzheimer's type. J. Neurochem. 1992, 59, 1646-1653. [CrossRef]

95. Pettegrew, J.W.; Panchalingam, K.; Hamilton, R.L.; McClure, R.J. Brain membrane phospholipid alterations in Alzheimer's disease. Neurochem. Res. 2001, 26, 771-782. [CrossRef]

96. Couttas, T.A.; Kain, N.; Daniels, B.; Lim, X.Y.; Shepherd, C.; Kril, J.; Pickford, R.; Li, H.; Garner, B.; Don, A.S. Loss of the neuroprotective factor Sphingosine 1-phosphate early in Alzheimer's disease pathogenesis. Acta Neuropathol. Commun. 2014, 2, 9. [CrossRef]

97. Han, X.; McKeel, D.W., Jr.; Kelley, J.; Morris, J.C. Substantial sulfatide deficiency and ceramide elevation in very early Alzheimer's disease: Potential role in disease pathogenesis. J. Neurochem. 2002, 82, 809-818. [CrossRef]

98. Brekk, O.R.; Honey, J.R.; Lee, S.; Hallett, P.J.; Isacson, O. Cell type-specific lipid storage changes in Parkinson's disease patient brains are recapitulated by experimental glycolipid disturbance. Proc. Natl. Acad. Sci. USA 2020, 117, 27646-27654. [CrossRef] [PubMed]

99. Chan, R.B.; Perotte, A.J.; Zhou, B.; Liong, C.; Shorr, E.J.; Marder, K.S.; Kang, U.J.; Waters, C.H.; Levy, O.A.; Xu, Y.; et al. Elevated GM3 plasma concentration in idiopathic Parkinson's disease: A lipidomic analysis. PLoS ONE 2017, 12, e0172348. [CrossRef] [PubMed]

100. Di Pardo, A.; Amico, E.; Basit, A.; Armirotti, A.; Joshi, P.; Neely, M.D.; Vuono, R.; Castaldo, S.; Digilio, A.F.; Scalabri, F.; et al. Defective Sphingosine-1-phosphate metabolism is a druggable target in Huntington's disease. Sci. Rep. 2017, 7, 5280. [CrossRef]

101. Kreilaus, F.; Spiro, A.S.; McLean, C.A.; Garner, B.; Jenner, A.M. Evidence for altered cholesterol metabolism in Huntington's disease post mortem brain tissue. Neuropathol. Appl. Neurobiol. 2016, 42, 535-546. [CrossRef] [PubMed]

102. Leoni, V.; Mariotti, C.; Nanetti, L.; Salvatore, E.; Squitieri, F.; Bentivoglio, A.R.; Bandettini di Poggio, M.; Piacentini, S.; Monza, D.; Valenza, M.; et al. Whole body cholesterol metabolism is impaired in Huntington's disease. Neurosci. Lett. 2011, 494, 245-249. [CrossRef] [PubMed]

103. Karasinska, J.M.; Hayden, M.R. Cholesterol metabolism in Huntington disease. Nat. Rev. Neurol. 2011, 7, 561-572. [CrossRef]

104. Cutler, R.G.; Pedersen, W.A.; Camandola, S.; Rothstein, J.D.; Mattson, M.P. Evidence that accumulation of ceramides and cholesterol esters mediates oxidative stress-induced death of motor neurons in amyotrophic lateral sclerosis. Ann. Neurol. 2002, 52, 448-457. [CrossRef]

105. Blasco, H.; Veyrat-Durebex, C.; Bocca, C.; Patin, F.; Vourc'h, P.; Kouassi Nzoughet, J.; Lenaers, G.; Andres, C.R.; Simard, G.; Corcia, P.; et al. Lipidomics Reveals Cerebrospinal-Fluid Signatures of ALS. Sci. Rep. 2017, 7, 17652. [CrossRef]

106. Del Boccio, P.; Pieragostino, D.; Di Ioia, M.; Petrucci, F.; Lugaresi, A.; De Luca, G.; Gambi, D.; Onofrj, M.; Di Ilio, C.; Sacchetta, P.; et al. Lipidomic investigations for the characterization of circulating serum lipids in multiple sclerosis. J. Proteomics 2011, 74, 2826-2836. [CrossRef]

107. Kim, W.S.; He, Y.; Phan, K.; Ahmed, R.M.; Rye, K.A.; Piguet, O.; Hodges, J.R.; Halliday, G.M. Altered High Density Lipoprotein Composition in Behavioral Variant Frontotemporal Dementia. Front. Neurosci. 2018, 12, 847. [CrossRef]

108. Ahmed, R.M.; MacMillan, M.; Bartley, L.; Halliday, G.M.; Kiernan, M.C.; Hodges, J.R.; Piguet, O. Systemic metabolism in frontotemporal dementia. Neurology 2014, 83, 1812-1818. [CrossRef]

109. Phan, K.; He, Y.; Pickford, R.; Bhatia, S.; Katzeff, J.S.; Hodges, J.R.; Piguet, O.; Halliday, G.M.; Kim, W.S. Uncovering pathophysiological changes in frontotemporal dementia using serum lipids. Sci. Rep. 2020, 10, 3640. [CrossRef] [PubMed]

110. Behrens, M.I.; Mukherjee, O.; Tu, P.H.; Liscic, R.M.; Grinberg, L.T.; Carter, D.; Paulsmeyer, K.; Taylor-Reinwald, L.; Gitcho, M.; Norton, J.B.; et al. Neuropathologic heterogeneity in HDDD1: A familial frontotemporal lobar degeneration with ubiquitinpositive inclusions and progranulin mutation. Alzheimer Dis. Assoc. Disord. 2007, 21, 1-7. [CrossRef] [PubMed]

111. Snowden, J.S.; Pickering-Brown, S.M.; Mackenzie, I.R.; Richardson, A.M.; Varma, A.; Neary, D.; Mann, D.M. Progranulin gene mutations associated with frontotemporal dementia and progressive non-fluent aphasia. Brain 2006, 129, 3091-3102. [CrossRef] [PubMed]

112. Evers, B.M.; Rodriguez-Navas, C.; Tesla, R.J.; Prange-Kiel, J.; Wasser, C.R.; Yoo, K.S.; McDonald, J.; Cenik, B.; Ravenscroft, T.A.; Plattner, F.; et al. Lipidomic and Transcriptomic Basis of Lysosomal Dysfunction in Progranulin Deficiency. Cell Rep. 2017, 20, 2565-2574. [CrossRef] [PubMed]

113. Smith, K.R.; Damiano, J.; Franceschetti, S.; Carpenter, S.; Canafoglia, L.; Morbin, M.; Rossi, G.; Pareyson, D.; Mole, S.E.; Staropoli, J.F.; et al. Strikingly different clinicopathological phenotypes determined by progranulin-mutation dosage. Am. J. Hum. Genet. 2012, 90, 1102-1107. [CrossRef]

114. Canafoglia, L.; Morbin, M.; Scaioli, V.; Pareyson, D.; D’Incerti, L.; Fugnanesi, V.; Tagliavini, F.; Berkovic, S.F.; Franceschetti, S. Recurrent generalized seizures, visual loss, and palinopsia as phenotypic features of neuronal ceroid lipofuscinosis due to progranulin gene mutation. Epilepsia 2014, 55, e56-e59. [CrossRef] 
115. Yin, F.; Dumont, M.; Banerjee, R.; Ma, Y.; Li, H.; Lin, M.T.; Beal, M.F.; Nathan, C.; Thomas, B.; Ding, A. Behavioral deficits and progressive neuropathology in progranulin-deficient mice: A mouse model of frontotemporal dementia. FASEB J. 2010, 24, 4639-4647.

116. Paushter, D.H.; Du, H.; Feng, T.; Hu, F. The lysosomal function of progranulin, a guardian against neurodegeneration. Acta Neuropathol. 2018, 136, 1-17. [CrossRef]

117. Strong, A.; Rader, D.J. Sortilin as a regulator of lipoprotein metabolism. Curr. Atheroscler. Rep. 2012, 14, 211-218. [CrossRef]

118. Zhou, X.; Sun, L.; Bracko, O.; Choi, J.W.; Jia, Y.; Nana, A.L.; Brady, O.A.; Hernandez, J.C.C.; Nishimura, N.; Seeley, W.W.; et al. Impaired prosaposin lysosomal trafficking in frontotemporal lobar degeneration due to progranulin mutations. Nat. Commun. 2017, 8, 15277. [CrossRef]

119. Arrant, A.E.; Roth, J.R.; Boyle, N.R.; Kashyap, S.N.; Hoffmann, M.Q.; Murchison, C.F.; Ramos, E.M.; Nana, A.L.; Spina, S.; Grinberg, L.T.; et al. Impaired beta-glucocerebrosidase activity and processing in frontotemporal dementia due to progranulin mutations. Acta Neuropathol. Commun. 2019, 7, 218. [CrossRef]

120. Van der Knaap, M.S.; Bugiani, M. Leukodystrophies: A proposed classification system based on pathological changes and pathogenetic mechanisms. Acta Neuropathol. 2017, 134, 351-382. [CrossRef] [PubMed]

121. Van der Knaap, M.S.; Schiffmann, R.; Mochel, F.; Wolf, N.I. Diagnosis, prognosis, and treatment of leukodystrophies. Lancet Neurol. 2019, 18, 962-972. [CrossRef]

122. Vanderver, A.; Prust, M.; Tonduti, D.; Mochel, F.; Hussey, H.M.; Helman, G.; Garbern, J.; Eichler, F.; Labauge, P.; Aubourg, P.; et al. Case definition and classification of leukodystrophies and leukoencephalopathies. Mol. Genet. Metab. 2015, 114, 494-500. [CrossRef] [PubMed]

123. Kohler, W.; Curiel, J.; Vanderver, A. Adulthood leukodystrophies. Nat. Rev. Neurol. 2018, 14, 94-105. [CrossRef] [PubMed]

124. Kevelam, S.H.; Steenweg, M.E.; Srivastava, S.; Helman, G.; Naidu, S.; Schiffmann, R.; Blaser, S.; Vanderver, A.; Wolf, N.I.; Van der Knaap, M.S. Update on Leukodystrophies: A Historical Perspective and Adapted Definition. Neuropediatrics 2016, 47, 349-354. [CrossRef] [PubMed]

125. Vanderver, A.; Simons, C.; Helman, G.; Crawford, J.; Wolf, N.I.; Bernard, G.; Pizzino, A.; Schmidt, J.L.; Takanohashi, A.; Miller, D.; et al. Whole exome sequencing in patients with white matter abnormalities. Ann. Neurol. 2016, 79, $1031-1037$. [CrossRef] [PubMed]

126. Penati, R.; Fumagalli, F.; Calbi, V.; Bernardo, M.E.; Aiuti, A. Gene therapy for lysosomal storage disorders: Recent advances for metachromatic leukodystrophy and mucopolysaccaridosis I. J. Inherit. Metab. Dis. 2017, 40, 543-554. [CrossRef]

127. Manolio, T.A.; Collins, F.S.; Cox, N.J.; Goldstein, D.B.; Hindorff, L.A.; Hunter, D.J.; McCarthy, M.I.; Ramos, E.M.; Cardon, L.R.; Chakravarti, A.; et al. Finding the missing heritability of complex diseases. Nature 2009, 461, 747-753. [CrossRef]

128. Tam, V.; Patel, N.; Turcotte, M.; Bosse, Y.; Pare, G.; Meyre, D. Benefits and limitations of genome-wide association studies. Nat. Rev. Genet. 2019, 20, 467-484. [CrossRef]

129. Van Deerlin, V.M.; Sleiman, P.M.; Martinez-Lage, M.; Chen-Plotkin, A.; Wang, L.S.; Graff-Radford, N.R.; Dickson, D.W.; Rademakers, R.; Boeve, B.F.; Grossman, M.; et al. Common variants at 7p21 are associated with frontotemporal lobar degeneration with TDP-43 inclusions. Nat. Genet. 2010, 42, 234-249. [CrossRef]

130. Finch, N.; Carrasquillo, M.M.; Baker, M.; Rutherford, N.J.; Coppola, G.; Dejesus-Hernandez, M.; Crook, R.; Hunter, T.; Ghidoni, R.; Benussi, L.; et al. TMEM106B regulates progranulin levels and the penetrance of FTLD in GRN mutation carriers. Neurology 2011, 76, 467-474. [CrossRef]

131. Gallagher, M.D.; Posavi, M.; Huang, P.; Unger, T.L.; Berlyand, Y.; Gruenewald, A.L.; Chesi, A.; Manduchi, E.; Wells, A.D.; Grant, S.F.A.; et al. A Dementia-Associated Risk Variant near TMEM106B Alters Chromatin Architecture and Gene Expression. Am. J. Hum. Genet. 2017, 101, 643-663. [CrossRef] [PubMed]

132. Pottier, C.; Zhou, X.; Perkerson, R.B., 3rd; Baker, M.; Jenkins, G.D.; Serie, D.J.; Ghidoni, R.; Benussi, L.; Binetti, G.; Lopez de Munain, A.; et al. Potential genetic modifiers of disease risk and age at onset in patients with frontotemporal lobar degeneration and GRN mutations: A genome-wide association study. Lancet Neurol. 2018, 17, 548-558. [CrossRef]

133. Rhinn, H.; Abeliovich, A. Differential Aging Analysis in Human Cerebral Cortex Identifies Variants in TMEM106B and GRN that Regulate Aging Phenotypes. Cell Syst. 2017, 4, 404-415. [CrossRef]

134. Ferrari, R.; Grassi, M.; Salvi, E.; Borroni, B.; Palluzzi, F.; Pepe, D.; D'Avila, F.; Padovani, A.; Archetti, S.; Rainero, I.; et al. A genome-wide screening and SNPs-to-genes approach to identify novel genetic risk factors associated with frontotemporal dementia. Neurobiol. Aging 2015, 36, 13-26. [CrossRef]

135. Ferrari, R.; Hernandez, D.G.; Nalls, M.A.; Rohrer, J.D.; Ramasamy, A.; Kwok, J.B.; Dobson-Stone, C.; Brooks, W.S.; Schofield, P.R.; Halliday, G.M.; et al. Frontotemporal dementia and its subtypes: A genome-wide association study. Lancet Neurol. 2014, 13, 686-699. [CrossRef]

136. Ferrari, R.; Wang, Y.; Vandrovcova, J.; Guelfi, S.; Witeolar, A.; Karch, C.M.; Schork, A.J.; Fan, C.C.; Brewer, J.B.; International FTD-Genomics Consortium (IFGC); et al. Genetic architecture of sporadic frontotemporal dementia and overlap with Alzheimer's and Parkinson's diseases. J. Neurol. Neurosurg. Psychiatry 2017, 88, 152-164. [CrossRef]

137. Broce, I.; Karch, C.M.; Wen, N.; Fan, C.C.; Wang, Y.; Tan, C.H.; Kouri, N.; Ross, O.A.; Hoglinger, G.U.; Muller, U.; et al. Immunerelated genetic enrichment in frontotemporal dementia: An analysis of genome-wide association studies. PLoS Med. 2018, $15, \mathrm{e} 1002487$. 
138. Karch, C.M.; Wen, N.; Fan, C.C.; Yokoyama, J.S.; Kouri, N.; Ross, O.A.; Hoglinger, G.; Muller, U.; Ferrari, R.; Hardy, J.; et al. Selective Genetic Overlap Between Amyotrophic Lateral Sclerosis and Diseases of the Frontotemporal Dementia Spectrum. JAMA Neurol. 2018, 75, 860-875. [CrossRef]

139. Zhang, M.; Ferrari, R.; Tartaglia, M.C.; Keith, J.; Surace, E.I.; Wolf, U.; Sato, C.; Grinberg, M.; Liang, Y.; Xi, Z.; et al. A C6orf10/LOC101929163 locus is associated with age of onset in C9orf72 carriers. Brain 2018, 141, 2895-2907. [CrossRef] [PubMed]

140. Taskesen, E.; Mishra, A.; Van der Sluis, S.; Ferrari, R.; International FTD-Genomics Consortium (IFGC); Veldink, J.H.; Van Es, M.A.; Smit, A.B.; Posthuma, D.; Pijnenburg, Y. Susceptible genes and disease mechanisms identified in frontotemporal dementia and frontotemporal dementia with Amyotrophic Lateral Sclerosis by DNA-methylation and GWAS. Sci. Rep. 2017, 7, 8899. [CrossRef]

141. Mishra, A.; Ferrari, R.; Heutink, P.; Hardy, J.; Pijnenburg, Y.; Posthuma, D.; International FTD-Genomics Consortium (IFGC). Gene-based association studies report genetic links for clinical subtypes of frontotemporal dementia. Brain 2017, 140, 1437-1446. [CrossRef] [PubMed]

142. Chen, J.A.; Wang, Q.; Davis-Turak, J.; Li, Y.; Karydas, A.M.; Hsu, S.C.; Sears, R.L.; Chatzopoulou, D.; Huang, A.Y.; Wojta, K.J.; et al. A multiancestral genome-wide exome array study of Alzheimer disease, frontotemporal dementia, and progressive supranuclear palsy. JAMA Neurol. 2015, 72, 414-422. [CrossRef]

143. Simons, C.; Dyment, D.; Bent, S.J.; Crawford, J.; D'Hooghe, M.; Kohlschutter, A.; Venkateswaran, S.; Helman, G.; Poll-The, B.T.; Makowski, C.C.; et al. A recurrent de novo mutation in TMEM106B causes hypomyelinating leukodystrophy. Brain 2017, 140, 3105-3111. [CrossRef] [PubMed]

144. Yu, M.; Arshad, M.; Wang, W.; Zhao, D.; Xu, L.; Zhou, L. LRRK2 mediated Rab8a phosphorylation promotes lipid storage. Lipids Health Dis. 2018, 17, 34. [CrossRef]

145. Ferrazza, R.; Cogo, S.; Melrose, H.; Bubacco, L.; Greggio, E.; Guella, G.; Civiero, L.; Plotegher, N. LRRK2 deficiency impacts ceramide metabolism in brain. Biochem. Biophys. Res. Commun. 2016, 478, 1141-1146. [CrossRef]

146. Mahley, R.W. Central Nervous System Lipoproteins: ApoE and Regulation of Cholesterol Metabolism. Arterioscler. Thromb. Vasc. Biol. 2016, 36, 1305-1315. [CrossRef] [PubMed]

147. Chacinska, A.; Koehler, C.M.; Milenkovic, D.; Lithgow, T.; Pfanner, N. Importing mitochondrial proteins: Machineries and mechanisms. Cell 2009, 138, 628-644. [CrossRef] [PubMed]

148. Sudre, C.H.; Cardoso, M.J.; Frost, C.; Barnes, J.; Barkhof, F.; Fox, N.; Ourselin, S. APOE $\varepsilon 4$ status is associated with white matter hyperintensities volume accumulation rate independent of AD diagnosis. Neurobiol. Aging 2017, 53, 67-75. [CrossRef]

149. Miklossy, J.; Arai, T.; Guo, J.P.; Klegeris, A.; Yu, S.; McGeer, E.G.; McGeer, P.L. LRRK2 expression in normal and pathologic human brain and in human cell lines. J. Neuropathol. Exp. Neurol. 2006, 65, 953-963. [CrossRef]

150. Lyall, D.M.; Harris, S.E.; Bastin, M.E.; Muñoz Maniega, S.; Murray, C.; Lutz, M.W.; Saunders, A.M.; Roses, A.D.; Valdés Hernández Mdel, C.; Royle, N.A.; et al. Alzheimer's disease susceptibility genes APOE and TOMM40, and brain white matter integrity in the Lothian Birth Cohort 1936. Neurobiol. Aging 2014, 35, 25-33. [CrossRef]

151. Ciani, M.; Benussi, L.; Bonvicini, C.; Ghidoni, R. Genome Wide Association Study and Next Generation Sequencing: A Glimmer of Light Toward New Possible Horizons in Frontotemporal Dementia Research. Front. Neurosci. 2019, 13, 506. [CrossRef]

152. Xu, Y.; Liu, X.; Shen, J.; Tian, W.; Fang, R.; Li, B.; Ma, J.; Cao, L.; Chen, S.; Li, G.; et al. The Whole Exome Sequencing Clarifies the Genotype- Phenotype Correlations in Patients with Early-Onset Dementia. Aging Dis. 2018, 9, 696-705. [CrossRef]

153. Boyle, E.A.; Li, Y.I.; Pritchard, J.K. An Expanded View of Complex Traits: From Polygenic to Omnigenic. Cell 2017, 169, 1177-1186. [CrossRef] [PubMed]

154. Blauwendraat, C.; Wilke, C.; Simon-Sanchez, J.; Jansen, I.E.; Reifschneider, A.; Capell, A.; Haass, C.; Castillo-Lizardo, M.; Biskup, S.; Maetzler, W.; et al. The wide genetic landscape of clinical frontotemporal dementia: Systematic combined sequencing of 121 consecutive subjects. Genet. Med. 2018, 20, 240-249. [CrossRef]

155. Breza, M.; Koutsis, G.; Karadima, G.; Potagas, C.; Kartanou, C.; Papageorgiou, S.G.; Paraskevas, G.P.; Kapaki, E.; Stefanis, L.; Panas, M. The different faces of the p. A53T alpha-synuclein mutation: A screening of Greek patients with parkinsonism and/or dementia. Neurosci. Lett. 2018, 672, 136-139. [CrossRef]

156. Ramos-Campoy, O.; Antonell, A.; Falgas, N.; Balasa, M.; Borrego-Ecija, S.; Rodriguez-Santiago, B.; Datta, D.; Armengol, L.; Fernandez-Villullas, G.; Bosch, B.; et al. Screening of dementia genes by whole-exome sequencing in Spanish patients with early-onset dementia: Likely pathogenic, uncertain significance and risk variants. Neurobiol. Aging 2020, 93, e1-e9. [CrossRef]

157. Pottier, C.; Bieniek, K.F.; Finch, N.; Van de Vorst, M.; Baker, M.; Perkersen, R.; Brown, P.; Ravenscroft, T.; Van Blitterswijk, M.; Nicholson, A.M.; et al. Whole-genome sequencing reveals important role for TBK1 and OPTN mutations in frontotemporal lobar degeneration without motor neuron disease. Acta Neuropathol. 2015, 130, 77-92. [CrossRef] [PubMed]

158. Pottier, C.; Ren, Y.; Perkerson, R.B., 3rd; Baker, M.; Jenkins, G.D.; Van Blitterswijk, M.; DeJesus-Hernandez, M.; Van Rooij, J.G.J.; Murray, M.E.; Christopher, E.; et al. Genome-wide analyses as part of the international FTLD-TDP whole-genome sequencing consortium reveals novel disease risk factors and increases support for immune dysfunction in FTLD. Acta Neuropathol. 2019, 137, 879-899. [CrossRef]

159. Williams, K.L.; Topp, S.; Yang, S.; Smith, B.; Fifita, J.A.; Warraich, S.T.; Zhang, K.Y.; Farrawell, N.; Vance, C.; Hu, X.; et al. CCNF mutations in amyotrophic lateral sclerosis and frontotemporal dementia. Nat. Commun. 2016, 7, 11253. [CrossRef] [PubMed]

160. Saracino, D.; Clot, F.; Camuzat, A.; Anquetil, V.; Hannequin, D.; Guyant-Marechal, L.; Didic, M.; Guillot-Noel, L.; Rinaldi, D.; Latouche, M.; et al. Novel VCP mutations expand the mutational spectrum of frontotemporal dementia. Neurobiol. Aging 2018, 72, e11-e14. [CrossRef] 
161. Philtjens, S.; Van Mossevelde, S.; Van der Zee, J.; Wauters, E.; Dillen, L.; Vandenbulcke, M.; Vandenberghe, R.; Ivanoiu, A.; Sieben, A.; Willems, C.; et al. Rare nonsynonymous variants in SORT1 are associated with increased risk for frontotemporal dementia. Neurobiol. Aging 2018, 66, e3-e10. [CrossRef]

162. Bonvicini, C.; Scassellati, C.; Benussi, L.; Di Maria, E.; Maj, C.; Ciani, M.; Fostinelli, S.; Mega, A.; Bocchetta, M.; Lanzi, G.; et al. Next Generation Sequencing Analysis in Early Onset Dementia Patients. J. Alzheimer's Dis. 2019, 67, 243-256. [CrossRef]

163. Ng, A.S.L.; Tan, Y.J.; Yi, Z.; Tandiono, M.; Chew, E.; Dominguez, J.; Macas, M.; Ng, E.; Hameed, S.; Ting, S.; et al. Targeted exome sequencing reveals homozygous TREM2 R47C mutation presenting with behavioral variant frontotemporal dementia without bone involvement. Neurobiol. Aging 2018, 68, e15-e19. [CrossRef] [PubMed]

164. Van der Zee, J.; Van Langenhove, T.; Kovacs, G.G.; Dillen, L.; Deschamps, W.; Engelborghs, S.; Matej, R.; Vandenbulcke, M.; Sieben, A.; Dermaut, B.; et al. Rare mutations in SQSTM1 modify susceptibility to frontotemporal lobar degeneration. Acta Neuropathol. 2014, 128, 397-410. [CrossRef] [PubMed]

165. Stockl, M.; Fischer, P.; Wanker, E.; Herrmann, A. Alpha-synuclein selectively binds to anionic phospholipids embedded in liquid-disordered domains. J. Mol. Biol. 2008, 375, 1394-1404. [CrossRef] [PubMed]

166. Bodner, C.R.; Dobson, C.M.; Bax, A. Multiple tight phospholipid-binding modes of alpha-synuclein revealed by solution NMR spectroscopy. J. Mol. Biol. 2009, 390, 775-790. [CrossRef]

167. Bodner, C.R.; Maltsev, A.S.; Dobson, C.M.; Bax, A. Differential phospholipid binding of alpha-synuclein variants implicated in Parkinson's disease revealed by solution NMR spectroscopy. Biochemistry 2010, 49, 862-871. [CrossRef]

168. Quazi, F.; Molday, R.S. Differential phospholipid substrates and directional transport by ATP-binding cassette proteins ABCA1, ABCA7, and ABCA4 and disease-causing mutants. J. Biol. Chem. 2013, 288, 34414-34426. [CrossRef] [PubMed]

169. Lynch, D.S.; Rodrigues Brandao de Paiva, A.; Zhang, W.J.; Bugiardini, E.; Freua, F.; Tavares Lucato, L.; Macedo-Souza, L.I.; Lakshmanan, R.; Kinsella, J.A.; Merwick, A.; et al. Clinical and genetic characterization of leukoencephalopathies in adults. Brain 2017, 140, 1204-1211. [CrossRef]

170. Parikh, S.; Bernard, G.; Leventer, R.J.; Van der Knaap, M.S.; Van Hove, J.; Pizzino, A.; McNeill, N.H.; Helman, G.; Simons, C.; Schmidt, J.L.; et al. A clinical approach to the diagnosis of patients with leukodystrophies and genetic leukoencephelopathies. Mol. Genet. Metab. 2015, 114, 501-515. [CrossRef]

171. Schneider, A.; Hasan, A.; Hirschel, S.; Wilhelm, C.; Kohlhase, J.; Falkai, P.; Gartner, J.; Steinfeld, R.; Wobrock, T.; Degner, D. A novel mutation of the arylsulfatase A gene in late-onset metachromatic leukodystrophy. J. Clin. Psychiatry 2009, 70, 1724-1725. [CrossRef]

172. Stoeck, K.; Psychogios, M.N.; Ohlenbusch, A.; Steinfeld, R.; Schmidt, J. Late-Onset Metachromatic Leukodystrophy with Early Onset Dementia Associated with a Novel Missense Mutation in the Arylsulfatase A Gene. J. Alzheimer's Dis. 2016, 51, 683-687. [CrossRef]

173. Gore, E.; Manley, A.; Dees, D.; Appleby, B.S.; Lerner, A.J. A young-onset frontal dementia with dramatic calcifications due to a novel CSF1R mutation. Neurocase 2016, 22, 257-262. [CrossRef]

174. Kawakami, I.; Iseki, E.; Kasanuki, K.; Minegishi, M.; Sato, K.; Hino, H.; Shibuya, K.; Fujisawa, K.; Higashi, S.; Akiyama, H.; et al. A family with hereditary diffuse leukoencephalopathy with spheroids caused by a novel c. $2442+2 \mathrm{~T}>\mathrm{C}$ mutation in the CSF1R gene. J. Neurol. Sci. 2016, 367, 349-355. [CrossRef] [PubMed]

175. Giraldo, M.; Lopera, F.; Siniard, A.L.; Corneveaux, J.J.; Schrauwen, I.; Carvajal, J.; Munoz, C.; Ramirez-Restrepo, M.; Gaiteri, C.; Myers, A.J.; et al. Variants in triggering receptor expressed on myeloid cells 2 are associated with both behavioral variant frontotemporal lobar degeneration and Alzheimer's disease. Neurobiol. Aging 2013, 34, e11-e18. [CrossRef] [PubMed]

176. Guerreiro, R.J.; Lohmann, E.; Bras, J.M.; Gibbs, J.R.; Rohrer, J.D.; Gurunlian, N.; Dursun, B.; Bilgic, B.; Hanagasi, H.; Gurvit, H.; et al. Using exome sequencing to reveal mutations in TREM2 presenting as a frontotemporal dementia-like syndrome without bone involvement. JAMA Neurol. 2013, 70, 78-84. [CrossRef] [PubMed]

177. Borroni, B.; Ferrari, F.; Galimberti, D.; Nacmias, B.; Barone, C.; Bagnoli, S.; Fenoglio, C.; Piaceri, I.; Archetti, S.; Bonvicini, C.; et al. Heterozygous TREM2 mutations in frontotemporal dementia. Neurobiol. Aging 2014, 35, e7-e10. [CrossRef] [PubMed]

178. Giannoccaro, M.P.; Bartoletti-Stella, A.; Piras, S.; Pession, A.; De Massis, P.; Oppi, F.; Stanzani-Maserati, M.; Pasini, E.; Baiardi, S.; Avoni, P.; et al. Multiple variants in families with amyotrophic lateral sclerosis and frontotemporal dementia related to C9orf72 repeat expansion: Further observations on their oligogenic nature. J. Neurol. 2017, 264, 1426-1433. [CrossRef] [PubMed]

179. Alexander, S.K.; Brown, J.M.; Graham, A.; Nestor, P.J. CADASIL presenting with a behavioural variant frontotemporal dementia phenotype. J. Clin. Neurosci. 2014, 21, 165-167. [CrossRef]

180. Sugama, S.; Kimura, A.; Chen, W.; Kubota, S.; Seyama, Y.; Taira, N.; Eto, Y. Frontal lobe dementia with abnormal cholesterol metabolism and heterozygous mutation in sterol 27-hydroxylase gene (CYP27). J. Inherit. Metab. Dis. 2001, 24, 379-392. [CrossRef]

181. Sirkis, D.W.; Geier, E.G.; Bonham, L.W.; Karch, C.M.; Yokoyama, J.S. Recent advances in the genetics of frontotemporal dementia. Curr. Genet. Med. Rep. 2019, 7, 41-52. [CrossRef] [PubMed]

182. Lang, C.M.; Fellerer, K.; Schwenk, B.M.; Kuhn, P.H.; Kremmer, E.; Edbauer, D.; Capell, A.; Haass, C. Membrane orientation and subcellular localization of transmembrane protein 106B (TMEM106B), a major risk factor for frontotemporal lobar degeneration. J. Biol. Chem. 2012, 287, 19355-19365. [CrossRef]

183. Brady, O.A.; Zheng, Y.; Murphy, K.; Huang, M.; Hu, F. The frontotemporal lobar degeneration risk factor, TMEM106B, regulates lysosomal morphology and function. Hum. Mol. Genet. 2013, 22, 685-695. [CrossRef] 
184. Chen-Plotkin, A.S.; Unger, T.L.; Gallagher, M.D.; Bill, E.; Kwong, L.K.; Volpicelli-Daley, L.; Busch, J.I.; Akle, S.; Grossman, M.; Van Deerlin, V.; et al. TMEM106B, the risk gene for frontotemporal dementia, is regulated by the microRNA-132/212 cluster and affects progranulin pathways. J. Neurosci. 2012, 32, 11213-11227. [CrossRef]

185. Cruchaga, C.; Graff, C.; Chiang, H.H.; Wang, J.; Hinrichs, A.L.; Spiegel, N.; Bertelsen, S.; Mayo, K.; Norton, J.B.; Morris, J.C.; et al. Association of TMEM106B gene polymorphism with age at onset in granulin mutation carriers and plasma granulin protein levels. Arch. Neurol. 2011, 68, 581-586. [CrossRef] [PubMed]

186. Van Blitterswijk, M.; Mullen, B.; Nicholson, A.M.; Bieniek, K.F.; Heckman, M.G.; Baker, M.C.; DeJesus-Hernandez, M.; Finch, N.A.; Brown, P.H.; Murray, M.E.; et al. TMEM106B protects C9ORF72 expansion carriers against frontotemporal dementia. Acta Neuropathol. 2014, 127, 397-406. [CrossRef] [PubMed]

187. Yan, H.; Kubisiak, T.; Ji, H.; Xiao, J.; Wang, J.; Burmeister, M. The recurrent mutation in TMEM106B also causes hypomyelinating leukodystrophy in China and is a CpG hotspot. Brain 2018, 141, e36. [CrossRef]

188. Ito, Y.; Hartley, T.; Baird, S.; Venkateswaran, S.; Simons, C.; Wolf, N.I.; Boycott, K.M.; Dyment, D.A.; Kernohan, K.D. Lysosomal dysfunction in TMEM106B hypomyelinating leukodystrophy. Neurol. Genet. 2018, 4, e288. [CrossRef]

189. Luningschror, P.; Werner, G.; Stroobants, S.; Kakuta, S.; Dombert, B.; Sinske, D.; Wanner, R.; Lullmann-Rauch, R.; Wefers, B.; Wurst, W.; et al. The FTLD Risk Factor TMEM106B Regulates the Transport of Lysosomes at the Axon Initial Segment of Motoneurons. Cell Rep. 2020, 30, 3506-3519. [CrossRef]

190. Zhou, X.; Nicholson, A.M.; Ren, Y.; Brooks, M.; Jiang, P.; Zuberi, A.; Phuoc, H.N.; Perkerson, R.B.; Matchett, B.; Parsons, T.M.; et al. Loss of TMEM106B leads to myelination deficits: Implications for frontotemporal dementia treatment strategies. Brain 2020, 143, 1905-1919. [CrossRef]

191. Urbik, V.M.; Schmiedel, M.; Soderholm, H.; Bonkowsky, J.L. Expanded Phenotypic Definition Identifies Hundreds of Potential Causative Genes for Leukodystrophies and Leukoencephalopathies. Child Neurol. Open 2020, 7, 2329048.

192. Bannwarth, S.; Ait-El-Mkadem, S.; Chaussenot, A.; Genin, E.C.; Lacas-Gervais, S.; Fragaki, K.; Berg-Alonso, L.; Kageyama, Y.; Serre, V.; Moore, D.G.; et al. A mitochondrial origin for frontotemporal dementia and amyotrophic lateral sclerosis through CHCHD10 involvement. Brain 2014, 137, 2329-2345. [CrossRef] [PubMed]

193. Rademakers, R.; Baker, M.; Nicholson, A.M.; Rutherford, N.J.; Finch, N.; Soto-Ortolaza, A.; Lash, J.; Wider, C.; Wojtas, A.; DeJesus-Hernandez, M.; et al. Mutations in the colony stimulating factor 1 receptor (CSF1R) gene cause hereditary diffuse leukoencephalopathy with spheroids. Nat. Genet. 2011, 44, 200-205. [CrossRef]

194. Tábuas-Pereira, M.; Santana, I.; Kun-Rodrigues, C.; Bras, J.; Guerreiro, R. CYLD variants in frontotemporal dementia associated with severe memory impairment in a Portuguese cohort. Brain 2020, 143, e67. [CrossRef]

195. Ryan, N.S.; Biessels, G.J.; Kim, L.; Nicholas, J.M.; Barber, P.A.; Walsh, P.; Gami, P.; Morris, H.R.; Bastos-Leite, A.J.; Schott, J.M.; et al. Genetic determinants of white matter hyperintensities and amyloid angiopathy in familial Alzheimer's disease. Neurobiol. Aging 2015, 36, 3140-3151. [CrossRef]

196. Tu, P.H.; Galvin, J.E.; Baba, M.; Giasson, B.; Tomita, T.; Leight, S.; Nakajo, S.; Iwatsubo, T.; Trojanowski, J.Q.; Lee, V.M. Glial cytoplasmic inclusions in white matter oligodendrocytes of multiple system atrophy brains contain insoluble alpha-synuclein. Ann. Neurol. 1998, 44, 415-422. [CrossRef] [PubMed]

197. Felsky, D.; Szeszko, P.; Yu, L.; Honer, W.G.; De Jager, P.L.; Schneider, J.A.; Malhotra, A.K.; Lencz, T.; Ikuta, T.; Pipitone, J.; et al. The SORL1 gene and convergent neural risk for Alzheimer's disease across the human lifespan. Mol. Psychiatry 2014, 19, 1125-1132. [CrossRef]

198. Kovacs, G.G.; Van der Zee, J.; Hort, J.; Kristoferitsch, W.; Leitha, T.; Höftberger, R.; Ströbel, T.; Van Broeckhoven, C.; Matej, R. Clinicopathological description of two cases with SQSTM1 gene mutation associated with frontotemporal dementia. Neuropathology 2016, 36, 27-38. [CrossRef]

199. Borroni, B.; Bonvicini, C.; Alberici, A.; Buratti, E.; Agosti, C.; Archetti, S.; Papetti, A.; Stuani, C.; Di Luca, M.; Gennarelli, M.; et al. Mutation within TARDBP leads to frontotemporal dementia without motor neuron disease. Hum. Mutat. 2009, 30, e974-e983. [CrossRef]

200. Synofzik, M.; Maetzler, W.; Grehl, T.; Prudlo, J.; Vom Hagen, J.M.; Haack, T.; Rebassoo, P.; Munz, M.; Schöls, L.; Biskup, S. Screening in ALS and FTD patients reveals 3 novel UBQLN2 mutations outside the PXX domain and a pure FTD phenotype. Neurobiol. Aging 2012, 33, e13-e17. [CrossRef]

201. Fahed, A.C.; McDonough, B.; Gouvion, C.M.; Newell, K.L.; Dure, L.S.; Bebin, M.; Bick, A.G.; Seidman, J.G.; Harter, D.H.; Seidman, C.E. UBQLN2 mutation causing heterogeneous X-linked dominant neurodegeneration. Ann. Neurol. 2014, 75, 793-798. [CrossRef]

202. Yeh, F.L.; Hansen, D.V.; Sheng, M. TREM2, Microglia, and Neurodegenerative Diseases. Trends Mol. Med. 2017, $23,512-533$. [CrossRef] [PubMed]

203. Paloneva, J.; Manninen, T.; Christman, G.; Hovanes, K.; Mandelin, J.; Adolfsson, R.; Bianchin, M.; Bird, T.; Miranda, R.; Salmaggi, A.; et al. Mutations in two genes encoding different subunits of a receptor signaling complex result in an identical disease phenotype. Am. J. Hum. Genet. 2002, 71, 656-662. [CrossRef] [PubMed]

204. Dardiotis, E.; Siokas, V.; Pantazi, E.; Dardioti, M.; Rikos, D.; Xiromerisiou, G.; Markou, A.; Papadimitriou, D.; Speletas, M.; Hadjigeorgiou, G.M. A novel mutation in TREM2 gene causing Nasu-Hakola disease and review of the literature. Neurobiol. Aging 2017, 53, e13-e22. [CrossRef] 
205. Kaneko, M.; Sano, K.; Nakayama, J.; Amano, N. Nasu-Hakola disease: The first case reported by Nasu and review: The 50th Anniversary of Japanese Society of Neuropathology. Neuropathology 2010, 30, 463-470. [CrossRef] [PubMed]

206. Chouery, E.; Delague, V.; Bergougnoux, A.; Koussa, S.; Serre, J.L.; Megarbane, A. Mutations in TREM2 lead to pure early-onset dementia without bone cysts. Hum. Mutat. 2008, 29, e194-e204. [CrossRef] [PubMed]

207. Nugent, A.A.; Lin, K.; Van Lengerich, B.; Lianoglou, S.; Przybyla, L.; Davis, S.S.; Llapashtica, C.; Wang, J.; Kim, D.J.; Xia, D.; et al TREM2 Regulates Microglial Cholesterol Metabolism upon Chronic Phagocytic Challenge. Neuron 2020, 105, 837-854. [CrossRef]

208. Konno, T.; Kasanuki, K.; Ikeuchi, T.; Dickson, D.W.; Wszolek, Z.K. CSF1R-related leukoencephalopathy: A major player in primary microgliopathies. Neurology 2018, 91, 1092-1104. [CrossRef] [PubMed]

209. Oosterhof, N.; Kuil, L.E.; Van der Linde, H.C.; Burm, S.M.; Berdowski, W.; Van Ijcken, W.F.J.; Van Swieten, J.C.; Hol, E.M.; Verheijen, M.H.G.; Van Ham, T.J. Colony-Stimulating Factor 1 Receptor (CSF1R) Regulates Microglia Density and Distribution, but Not Microglia Differentiation In Vivo. Cell Rep. 2018, 24, 1203-1217. [CrossRef]

210. Sundal, C.; Fujioka, S.; Van Gerpen, J.A.; Wider, C.; Nicholson, A.M.; Baker, M.; Shuster, E.A.; Aasly, J.; Spina, S.; Ghetti, B.; et al. Parkinsonian features in hereditary diffuse leukoencephalopathy with spheroids (HDLS) and CSF1R mutations. Parkinsonism Relat. Disord. 2013, 19, 869-877. [CrossRef]

211. Wong, J.C.; Chow, T.W.; Hazrati, L.N. Adult-onset leukoencephalopathy with axonal spheroids and pigmented glia can present as frontotemporal dementia syndrome. Dement. Geriatr. Cogn. Disord. 2011, 32, 150-158. [CrossRef] [PubMed]

212. Robinson, J.L.; Suh, E.; Wood, E.M.; Lee, E.B.; Coslett, H.B.; Raible, K.; Lee, V.M.; Trojanowski, J.Q.; Van Deerlin, V.M. Common neuropathological features underlie distinct clinical presentations in three siblings with hereditary diffuse leukoencephalopathy with spheroids caused by CSF1R p. Arg782His. Acta Neuropathol. Commun. 2015, 3, 42. [CrossRef] [PubMed]

213. Kraya, T.; Quandt, D.; Pfirrmann, T.; Kindermann, A.; Lampe, L.; Schroeter, M.L.; Kohlhase, J.; Stoevesandt, D.; Hoffmann, K.; Villavicencio-Lorini, P. Functional characterization of a novel CSF1R mutation causing hereditary diffuse leukoencephalopathy with spheroids. Mol. Genet. Genomic. Med. 2019, 7, e00595. [CrossRef] [PubMed]

214. Nie, S.; Chen, G.; Cao, X.; Zhang, Y. Cerebrotendinous xanthomatosis: A comprehensive review of pathogenesis, clinical manifestations, diagnosis, and management. Orphanet. J. Rare Dis. 2014, 9, 179. [CrossRef] [PubMed]

215. Franklin, R.J.; Ffrench-Constant, C. Remyelination in the CNS: From biology to therapy. Nat. Rev. Neurosci. 2008, 9, 839-855. [CrossRef] [PubMed]

216. Gibson, E.M.; Purger, D.; Mount, C.W.; Goldstein, A.K.; Lin, G.L.; Wood, L.S.; Inema, I.; Miller, S.E.; Bieri, G.; Zuchero, J.B.; et al. Neuronal activity promotes oligodendrogenesis and adaptive myelination in the mammalian brain. Science 2014, 344, 1252304. [CrossRef] [PubMed]

217. Llorens-Bobadilla, E.; Chell, J.M.; Le Merre, P.; Wu, Y.; Zamboni, M.; Bergenstråhle, J.; Stenudd, M.; Sopova, E.; Lundeberg, J.; Shupliakov, O.; et al. A latent lineage potential in resident neural stem cells enables spinal cord repair. Science 2020, $370,6512$. [CrossRef]

218. Klein, Z.A.; Takahashi, H.; Ma, M.; Stagi, M.; Zhou, M.; Lam, T.T.; Strittmatter, S.M. Loss of TMEM106B Ameliorates Lysosomal and Frontotemporal Dementia-Related Phenotypes in Progranulin-Deficient Mice. Neuron 2017, 95, 281-296. [CrossRef]

219. Nicholson, A.M.; Zhou, X.; Perkerson, R.B.; Parsons, T.M.; Chew, J.; Brooks, M.; DeJesus-Hernandez, M.; Finch, N.A.; Matchett, B.J.; Kurti, A.; et al. Loss of Tmem106b is unable to ameliorate frontotemporal dementia-like phenotypes in an AAV mouse model of C9ORF72-repeat induced toxicity. Acta Neuropathol. Commun. 2018, 6, 42. [CrossRef] [PubMed]

220. Beckmann, N.; Giorgetti, E.; Neuhaus, A.; Zurbruegg, S.; Accart, N.; Smith, P.; Perdoux, J.; Perrot, L.; Nash, M.; Desrayaud, S.; et al. Brain region-specific enhancement of remyelination and prevention of demyelination by the CSF1R kinase inhibitor BLZ945. Acta Neuropathol. Commun. 2018, 6, 9. [CrossRef]

221. Tahmasebi, F.; Pasbakhsh, P.; Mortezaee, K.; Madadi, S.; Barati, S.; Kashani, I.R. Effect of the CSF1R inhibitor PLX3397on remyelination of corpus callosum in a cuprizone-induced demyelination mouse model. J. Cell Biochem. 2019, 120, 10576-10586. [CrossRef] [PubMed]

222. Cignarella, F.; Filipello, F.; Bollman, B.; Cantoni, C.; Locca, A.; Mikesell, R.; Manis, M.; Ibrahim, A.; Deng, L.; Benitez, B.A.; et al. TREM2 activation on microglia promotes myelin debris clearance and remyelination in a model of multiple sclerosis. Acta Neuropathol. 2020, 140, 513-534. [CrossRef]

223. Cullen, C.L.; Young, K.M. How Does Transcranial Magnetic Stimulation Influence Glial Cells in the Central Nervous System? Front. Neural. Circuits 2016, 10, 26. [CrossRef]

224. Choi, E.H.; Blasiak, A.; Lee, J.; Yang, I.H. Modulation of Neural Activity for Myelination in the Central Nervous System. Front. Neurosci. 2019, 13, 952. [CrossRef]

225. Prasad, A.; Teh, D.B.L.; Blasiak, A.; Chai, C.; Wu, Y.; Gharibani, P.M.; Yang, I.H.; Phan, T.T.; Lim, K.L.; Yang, H.; et al. Static Magnetic Field Stimulation Enhances Oligodendrocyte Differentiation and Secretion of Neurotrophic Factors. Sci. Rep. 2017, 7, 6743. [CrossRef] [PubMed]

226. Dolgova, N.; Wei, Z.; Spink, B.; Gui, L.; Hua, Q.; Truong, D.; Zhang, Z.; Zhang, Y. Low-Field Magnetic Stimulation Accelerates the Differentiation of Oligodendrocyte Precursor Cells via Non-canonical TGF-beta Signaling Pathways. Mol. Neurobiol. 2020, 58, 855-866. [CrossRef] [PubMed]

227. Cullen, C.L.; Senesi, M.; Tang, A.D.; Clutterbuck, M.T.; Auderset, L.; O’Rourke, M.E.; Rodger, J.; Young, K.M. Low-intensity transcranial magnetic stimulation promotes the survival and maturation of newborn oligodendrocytes in the adult mouse brain. Glia 2019, 67, 1462-1477. [CrossRef] [PubMed] 
228. Chalfouh, C.; Guillou, C.; Hardouin, J.; Delarue, Q.; Li, X.; Duclos, C.; Schapman, D.; Marie, J.P.; Cosette, P.; Guerout, N. The Regenerative Effect of Trans-spinal Magnetic Stimulation after Spinal Cord Injury: Mechanisms and Pathways Underlying the Effect. Neurotherapeutics 2020, 17, 2069-2088. [CrossRef] [PubMed]

229. Tergau, F.; Naumann, U.; Paulus, W.; Steinhoff, B.J. Low-frequency repetitive transcranial magnetic stimulation improves intractable epilepsy. Lancet 1999, 353, 2209. [CrossRef]

230. Randver, R. Repetitive transcranial magnetic stimulation of the dorsolateral prefrontal cortex to alleviate depression and cognitive impairment associated with Parkinson's disease: A review and clinical implications. J. Neurol. Sci. 2018, 393, 88-99. [CrossRef]

231. Rajji, T.K. Transcranial Magnetic and Electrical Stimulation in Alzheimer's Disease and Mild Cognitive Impairment: A Review of Randomized Controlled Trials. Clin. Pharmacol. Ther. 2019, 106, 776-780. [CrossRef]

232. Fang, J.; Zhou, M.; Yang, M.; Zhu, C.; He, L. Repetitive transcranial magnetic stimulation for the treatment of amyotrophic lateral sclerosis or motor neuron disease. Cochrane Database Syst. Rev. 2013, 5, CD008554. [CrossRef] [PubMed]

233. Croarkin, P.E.; MacMaster, F.P. Transcranial Magnetic Stimulation for Adolescent Depression. Child Adolesc. Psychiatr. Clin. N. Am. 2019, 28, 33-43. [CrossRef] [PubMed]

234. Gaynes, B.N.; Lloyd, S.W.; Lux, L.; Gartlehner, G.; Hansen, R.A.; Brode, S.; Jonas, D.E.; Swinson Evans, T.; Viswanathan, M.; Lohr, K.N. Repetitive transcranial magnetic stimulation for treatment-resistant depression: A systematic review and meta-analysis. J. Clin. Psychiatry 2014, 75, 477-489. [CrossRef]

235. Dougall, N.; Maayan, N.; Soares-Weiser, K.; McDermott, L.M.; McIntosh, A. Transcranial Magnetic Stimulation for Schizophrenia. Schizophr. Bull. 2015, 41, 1220-1222. [CrossRef]

236. Mehta, U.M.; Naik, S.S.; Thanki, M.V.; Thirthalli, J. Investigational and Therapeutic Applications of Transcranial Magnetic Stimulation in Schizophrenia. Curr. Psychiatry Rep. 2019, 21, 89. [CrossRef]

237. Kozel, F.A. Clinical Repetitive Transcranial Magnetic Stimulation for Posttraumatic Stress Disorder, Generalized Anxiety Disorder, and Bipolar Disorder. Psychiatr. Clin. N. Am. 2018, 41, 433-446. [CrossRef]

238. Antal, A.; Alekseichuk, I.; Bikson, M.; Brockmoller, J.; Brunoni, A.R.; Chen, R.; Cohen, L.G.; Dowthwaite, G.; Ellrich, J.; Floel, A.; et al. Low intensity transcranial electric stimulation: Safety, ethical, legal regulatory and application guidelines. Clin. Neurophysiol. 2017, 128, 1774-1809. [CrossRef]

239. Hadley, D.; Anderson, B.S.; Borckardt, J.J.; Arana, A.; Li, X.; Nahas, Z.; George, M.S. Safety, tolerability, and effectiveness of high doses of adjunctive daily left prefrontal repetitive transcranial magnetic stimulation for treatment-resistant depression in a clinical setting. J. ECT 2011, 27, 18-25. [CrossRef]

240. Benussi, A.; Dell’Era, V.; Cosseddu, M.; Cantoni, V.; Cotelli, M.S.; Cotelli, M.; Manenti, R.; Benussi, L.; Brattini, C.; Alberici, A.; et al. Transcranial stimulation in frontotemporal dementia: A randomized, double-blind, sham-controlled trial. Alzheimer's Dement. 2020, 6, e12033. [CrossRef] [PubMed] 